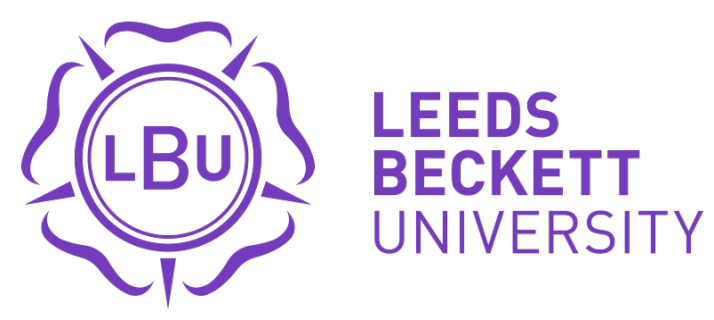

Citation:

Shahbaz, M and Nasir, M and Roubaud, D (2018) Environmental Degradation in France: The Effects of FDI, Financial Development, and Energy Innovations. Energy Economics, 74. pp. 843-857. ISSN 0140-9883 DOI: https://doi.org/10.1016/j.eneco.2018.07.020

Link to Leeds Beckett Repository record:

https://eprints.leedsbeckett.ac.uk/id/eprint/5190/

Document Version:

Article (Accepted Version)

The aim of the Leeds Beckett Repository is to provide open access to our research, as required by funder policies and permitted by publishers and copyright law.

The Leeds Beckett repository holds a wide range of publications, each of which has been checked for copyright and the relevant embargo period has been applied by the Research Services team.

We operate on a standard take-down policy. If you are the author or publisher of an output and you would like it removed from the repository, please contact us and we will investigate on a case-by-case basis.

Each thesis in the repository has been cleared where necessary by the author for third party copyright. If you would like a thesis to be removed from the repository or believe there is an issue with copyright, please contact us on openaccess@leedsbeckett.ac.uk and we will investigate on a case-by-case basis. 


\section{Accepted Manuscript}

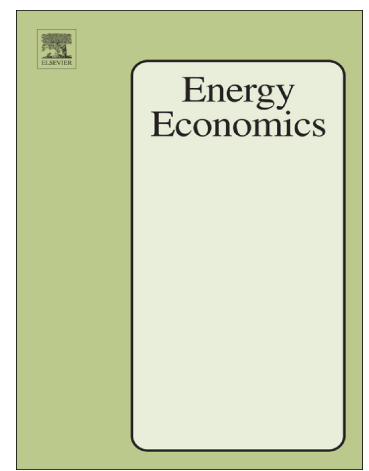

Muhammad Shahbaz, Muhammad Ali Nasir, David Roubaud

PII: $\quad$ S0140-9883(18)30270-6

DOI: $\quad$ doi:10.1016/j.eneco.2018.07.020

Reference: $\quad$ ENEECO 4099

To appear in: $\quad$ Energy Economics

Received date: $\quad 5$ March 2018

Revised date: $\quad 21$ July 2018

Accepted date: $\quad 23$ July 2018

Please cite this article as: Muhammad Shahbaz, Muhammad Ali Nasir, David Roubaud, Environmental Degradation in France: The Effects of FDI, Financial Development, and Energy Innovations. Eneeco (2018), doi:10.1016/j.eneco.2018.07.020

This is a PDF file of an unedited manuscript that has been accepted for publication. As a service to our customers we are providing this early version of the manuscript. The manuscript will undergo copyediting, typesetting, and review of the resulting proof before it is published in its final form. Please note that during the production process errors may be discovered which could affect the content, and all legal disclaimers that apply to the journal pertain. 


\title{
Environmental Degradation in France: The Effects of FDI, Financial Development, and Energy Innovations
}

\author{
Muhammad Shahbaz \\ Montpellier Business School, France \\ Email: muhdshahbaz77@gmail.com \\ Muhammad Ali Nasir ${ }^{1, *}$ \\ Leeds Business School, Leeds Beckett University \\ Email: m.a.nasir@leedsbeckett.ac.uk \\ David Roubaud \\ Montpellier Business School, France \\ Email: d.roubaud@montpellier-bs.com
}

\begin{abstract}
This paper explores the determinants of carbon emissions in France by accounting for the significant role played by foreign direct investment (FDI), financial development, economic growth, energy consumption and energy research innovations in influencing $\mathrm{CO}_{2}$ emissions function. In this endeavour, we employ the novel SOR (Shahbaz et al. 2017) unit root test on French time series data over the period 1955-2016 to examine the order of integration in the presence of sharp and smooth structural breaks in the variables. We also apply the bootstrapping bounds testing approach, recently developed by McNown et al. (2018), to investigate the presence of cointegration and the empirical findings underscore the presence of cointegration among the time series. Moreover, we find that FDI has a positive impact, while energy research innovations have a negative impact, on French carbon emissions. Financial development lowers carbon emissions, thereby improving the French environmental quality. FDI degrades the environment, and thus supports the pollution-haven hypothesis in France. Similarly, financial development suggests that financial stability is a required condition for improving environmental quality, so are energy research innovations. Contrarily, energy consumption is positively linked with carbon emissions. However, the relationship between economic growth and $\mathrm{CO}_{2}$ emissions is an inverted-U, which is a validation of the environmental Kuznets curve (EKC).
\end{abstract}

Keywords: FDI, Carbon Emissions, Financial Development, Energy Research Innovations JEL Codes: F21, O13, P18, Q43

\footnotetext{
${ }^{1}$ *Corresponding author: Economics, Analytics \& International Business Group, Leeds Business School, Leeds Beckett University, The Rose Bowl, Portland Crescent, Leeds, LS1 3HB, UK, Email: m.a.nasir@leedsbeckett.ac.uk, Telephone: 0044(0)7508457981
} 


\section{Introduction}

The US withdrawal from the Paris Agreement (i.e., Conference of the Paris or COP: 21) has created grave economic and ecological consequences ${ }^{2}$, such as a backlash for the US and global leadership who desire to tackle the environmental challenges and issues surrounding climate change (Leiserowitz et al., 2016; Hultman, 2017; Saha and Muro, 2017). On a positive note and in response to the US withdrawal, the European Union (EU) and China have announced they will strengthen their collaboration and step-up their efforts to deal with climate change (Financial Times, 2017). Additionally, in response to the Lima Call for Climate Action, the EU and its member states have committed to a target of a $40 \%$ domestic reduction in greenhouse gas emissions by 2030, compared to the 1990 levels (United Nations Framework Convention on Climate Change, 2018). Perhaps, the country showing the most remarkable leadership in response to the US withdrawal is France, which announced the continuation of efforts to tackle this issue (Reuters, 2017). In her efforts to address climate change, France hosted the "One Planet Summit" two years after the Paris agreement was held in December $2015 .^{3}$ In order to match ambitions with reality, it is necessary to take into account the crucial factors which cause environmental degradation in this country. Furthermore, it is also vital to contextualise the economic realities and challenges faced by the French economy which can have profound implications for her ability to deliver on the promises and plans for dealing with environmental challenges.

As it stands, economic growth in France has been anemic since the 2008-2009 global financial crisis (GFC), which was followed by the European sovereign debt crisis. The youth unemployment in this country is around $24 \%$, and public debt has reached a very high level that is in excess of $90 \%$, compared to the annual national income (Kottasová, 2017). Keeping that in context, France needs structural reforms of its economy, aiming in particular at the liberalisation of the labour market and the regulatory regime, as well as a massive boost of investment (See the detailed report of the OECD, 2014). Consequently, France is committed to encouraging foreign direct investments (FDI) as a way to create jobs and stimulate

\footnotetext{
${ }^{2}$ At the Paris Climate Conference (COP21) which was held in December 2015, for the first time ever, a large number of sovereign nations (195 countries + USA), adopted a universal and unanimously agreed global climate deal. A global action plan was put in place so that the global warming increase could be limited to $2^{\circ} \mathrm{C}$ (Morgan, 2016). On June 1, 2017, President Trump announced the withdrawal of US from the Paris Agreement as part of America First Policy (Easley, 2017). The implementation of COP21 can have important implications for the usage of fossil fuel and hence for the investors, however, these risks can be managed by portfolio diversification (see Batten et al. 2018) for details.

${ }^{3}$ The One Planet Summit is hosted by France with the aim of taking tangible and collective actions, innovating, and supporting one another. The details are available at http://www.climatefinanceday.com/one-planet-summit/.
} 
economic growth (Business France, 2017). It is worth noting that where FDI has declined at the global level, France was able to attract a noteworthy amount of FDI in 2017. The flows of FDI to France increased from $\$ 28$ billion to around $\$ 50$ billion in 2017 that is an increase of $77 \%$ which made France the world's 9th top country in term of FDI inflows in that year (See, UNCTD, 2018).

Undoubtedly, FDI plays an important role in economic growth and development of an economy, particularly when the indigenous savings are not sufficient to cater for domestic investment needs (see OECD, 2002 for the detailed discussion on the role of FDI in development and growth). But while FDI is important for economic growth and development, it may also be a cause for concern when considering the ecological consequences of an FDIled economic growth. The existing empirical evidence on the nexus between FDI and environmental degradation is inconclusive (detailed discussion in next section). Perhaps, the inconclusiveness and contrast are due to the fact that on theoretical grounds the nexus between FDI and environment has three key dimensions. First, according to the pollutionhaven hypothesis, a weak environmental regulation in a host country may attract inward FDI by profit-driven companies eager to circumvent costly regulatory compliance in their home countries. Hence, this line of reasoning implies that FDI will further lead to environmental degradation. Second, the pollution-halo hypothesis reveals that in applying a universal environmental standard, multinationals engaging in FDI will tend to spread their greener technology to their counterparts in the host country. The opposite potential effects imply that FDI may have positive or negative effects and lead to an improvement of environmental quality or more environmental degradation. Lastly, this nexus is also explained through the lens of the scale-effect hypothesis. The latter suggests that a scale effect would arise to the extent that multinational FDI operations would significantly contribute to a host nation's industrial output and, in turn, overall pollution level (environmental degradation) is increased (see, Pao and Tsai, 2011). In the case of the French economy, identifying which aspect of the nexus between FDI and environment is the most dominant has a profound implication and would provide important insight into the costs and benefits that it may harbour.

The financial sector plays an important role in the development and stability of an economy. The GFC revived the debate on the importance of the financial sector for real economy. It is evident that financial and economic stabilities are two sides of the same coin (see, for instance, Borio, 2011; Nasir et al., 2015). It is also important to consider the environmental consequences of the financial sector, particularly the role financial development plays in environmental degradation. There are three important channels which 
explain the nexus between financial development and energy consumption. First, financial development attracts more FDI and enhances economic growth, which leads to an increase in energy consumption. Second, the process of an efficient financial intermediation caused by the development of financial sector creates more consumer credit and a surge in the purchases of energy-consuming goods and services. Third, the development of financial and capital markets facilitates investments and leads to an increase in energy consumption (See Zhang, 2011). Of course one may argue that in the environmental context, the question is not whether financial development increases energy consumption as the main question is whether the end results would be an increase in $\mathrm{CO}_{2}$ emissions i.e. environmental degradation.

The existing evidence on the role of the financial sector development in affecting environmental degradation is mixed and inconclusive (contrast, Tamazian and Rao, 2010; Ozturk and Acaravci, 2013; Shahbaz et al., 2016; Bekhet et al., 2017; Salahuddin et al., 2018). However, Chang (2015) argues that financial development may offer more opportunities to develop the renewable energy sector by providing more funds to innovative firms. Furthermore, FDI can lead to more technological innovations and, thus helps reduce energy intensity. This raises other questions, which are whether or not such a notion prevails in the case of France and how financial development influences the French environmental degradation.

Nonetheless in this nexus, an important factor to consider is the technological innovations, which can be helpful in switching to more sustainable sources of energy including renewables (see, for example, Arrow et al., 1996; Torras and Boyce, 1998; Andreoni and Levinson, 2001; Lorente and Álvarez- Herránz, 2016; Álvarez-Herránz et al., 2017). Torras and Boyce (1998, P. 148) state "There is no a priori reason to assume the relationship between income and environmental quality to be strictly monotonic". Although the authors are referring to the role of technology in moderating this relationship, it would be logical to argue that the relationship between environmental quality and all of its determinants can be moderated by technological innovations. However, an important point to consider here is that innovation related to energy is more prone to influence energy consumption and, hence, carbon emissions, specifically energy innovations which are intuitively more relevant and important for environmental quality (Balsalobre-Lorente, 2018).

This paper contributes to the existing literature in five ways: (i) It examines the relationship between FDI and carbon emissions in the context of the environmental Kuznets curve (EKC) for the French economy. (ii) It considers whether financial development and public budget in energy research \& development expenditures are important factors affecting 
carbon emissions. (iii) It applies the sharp and smooth structural break unit root test in order to examine the stationary properties of the variables. (iv) It applies the bootstrapping boundstesting approach that was recently developed by McNown et al. (2018) in order to examine the cointegration between carbon emissions and its determinists. The ARDL bounds testing approach has been subject to a number of developments since its inception by Pesaran et al. (2001). For instance, among most remarkable contributors, Li and Lee (2011) introduced single ARDL test, Shin et al. (2014) accounted for the nonlinearities which named as Nonlinear-ARDL test, Li (2017) introduced a System ARDL test. In the recent developments using bootstrap techniques, McNown et al. (2018) have presented a bootstrap-ARDL bounds test which has a number of unique features giving it a competitive edge over its predecessors. For instance, the bootstrap approach has the ability to eradicate the likelihood of drawing inconclusive inferences. The second advantage of this approach which has also been supported by the evidence is that the endogeneity issue either does not arise or have very negligible effects on the properties (size and power) when the asymptotic critical values from the Monte Carlo simulations are employed. It's worth noting that the asymptotic test in the ARDL bounds test based on size and power properties is outperformed by bootstrap test, once we appropriately apply the resampling procedure. Lastly, considering the fact that we have critical values generated by the bootstrap procedure which used to present an extension of the ARDL bounds testing framework for the alternative degenerate case, a better insight is gained into the cointegration status of the series in the model by using the bootstrap ARDL test. (v) It investigates the causal relationship between carbon emissions and their determinants by applying the bootstrapping ARDL-based Granger causality test. Our key empirical findings suggest the presence of cointegration between the variables. The results also indicate that FDI has a positive and significant effect on carbon emissions. The relationship between economic growth and $\mathrm{CO}_{2}$ emissions is an inverted-U (i.e., validation of the environmental Kuznets curve). On the other hand, it shows that financial development improves environmental quality by lowering carbon emissions. Similarly, the relationship between research and development expenditures on energy innovation and carbon emissions is negative. Energy consumption is positively linked with carbon emissions. The causality analysis reveals that there a feedback effect between FDI and carbon emissions. Economic growth positively causes carbon emissions and in response, carbon emissions negatively cause economic growth. Financial development positively affects carbon emissions, but a similar relationship is not true from the opposite side. The relationship between research \& development expenditures and carbon emission is bidirectional but negative. Our findings shed light on 
economic realities and important factors which can influence environmental degradation in France. Hence, they have profound implications for economic and environmental policy formulation to achieve sustainable economic growth and emissions targets in general, and particularly in France.

The remainder of the paper proceeds as follows: Section 2 reviews the existing evidence of the subject. Section 3 details the model construction and data collection; Section 4 presents the methodological strategy. Section 5 discusses the empirical findings, and Section 6 presents the conclusion with policy implications.

\section{Literature Review}

This paper explores the relationship between FDI, economic growth, financial development, energy innovations and carbon emissions. For coherence, we divide the literature review into four segments. These segments are the FDI-emissions nexus, the nexus between economic growth and carbon emissions, the financial development-carbon emission nexus, and the relationship between energy innovations and carbon emissions. In the following lines, we will reflect on each nexus by drawing on the existing and relevant evidence.

\subsection{FDI-Emissions Nexus}

The importance of FDI to economic growth, particularly in countries like France with unmet investment needs, is undoubtedly paramount. However, it is important to consider the literature that addresses the FDI environmental consequences. Theoretically, FDI can have positive as well as negative effects on the environment, depending on which channel or dimension is dominant. As discussed earlier in the introduction, there are three dimensions to this relationship: the pollution-haven hypothesis, the pollution-halo hypothesis, and the scale effects hypothesis (Pao and Tsai, 2011). Concomitantly, there can be a varying impact of FDI on environmental quality, and perhaps, for this reason, the empirical evidence suggests mixed empirical results. For instance, while analysing the FDI effect of $\mathrm{CO}_{2}$ emissions in China, Ren et al. (2014) reported that FDI contributes to $\mathrm{CO}_{2}$ emissions. They also refute the argument put forward by Pao and Tsai's (2011) analysis of BRICS, which suggests that FDI spread greener technology to the host country and lead to environmental improvements in the developing countries. However, later studies by Zhang and Zhou (2016), using Chinese regional data, and Liu et al. (2017) and Jiang et al. (2017), using Chinese city-level data, report negative effects of FDI on $\mathrm{CO}_{2}$ emissions. It implies that even in a single country 
(China), we have mixed evidence. In evidence from other emerging economies, such as studies on Malaysia by Hitam and Borhan (2012) and Lau et al. (2014) report that although FDI promotes higher economic growth, it also leads to higher environmental degradation.

Tang and Tan (2015) report that income and FDI are the main determinants of increasing $\mathrm{CO}_{2}$ emissions in Vietnam. In case of the ASEAN-5 countries, Chandran and Tang (2013) indicate that FDI leads to a significant increase in energy consumption and $\mathrm{CO}_{2}$ emissions, although there are some country-level heterogeneities in the relationship. Similarly, a study by Zhu et al. (2016) on the ASEAN-5 countries, which employs the Panel Quantile Regression, reports that FDI has a negative effect on carbon emissions, except at the 5th quantile, and becomes significant at higher quantiles. Contrarily, Baek (2016) applies the pooled mean group (PMG) estimator of the dynamic panel in the case of the ASEAN-5 countries and shows that FDI tends to increase $\mathrm{CO}_{2}$ emissions. Similarly, Paramati et al. (2016) examine the relationship between FDI inflows and carbon emissions using data of emerging economies. ${ }^{4}$ They reveal that economic FDI inflows have a positive and significant impact on clean energy consumption as well as $\mathrm{CO}_{2}$ emissions. This implies that it is important to consider the country level heterogeneity to see which channel is dominant in the nexus between FDI and carbon emissions.

Among the studies on the natural resources abundant in Middle Eastern countries, Sbia et al. (2014) indicate that FDI leads to an increase in green energy consumption, and yet also an increase in $\mathrm{CO}_{2}$ emissions in United Arab Emirates (UAE). Similarly, when studying GCC countries, Al-mulali and Tang (2013) report that although FDI has no significant short-run causal relationship with $\mathrm{CO}_{2}$ emissions, in the long run, FDI inflows negatively affect $\mathrm{CO}_{2}$ emissions. Contrarily, Abdouli and Hammami (2017) indicate the occurrence of unidirectional causality running from FDI stocks to $\mathrm{CO}_{2}$ emissions in MENA countries, although there were country-level differences. However, Kivyiro and Arminen (2014) show mixed empirical results in six sub-Saharan countries, but in the case of Ghana, Solarin et al. (2017) indicate that FDI has a positive effect on $\mathrm{CO}_{2}$ emissions.

These mixed results signify the importance of considering country-level idiosyncrasies, which is the rationale to focus on France. Perhaps, the level of a country's development may play an important role in the subject nexus, which will then imply heterogeneity between the developed and developing economies. For instance, while analysing developing countries, Mielnik and Goldemberg (2002) report that FDI leads to a

\footnotetext{
${ }^{4}$ Brazil, Chile, China, Colombia, the Czech Republic, Egypt, Greece, Hungary, India, Indonesia, Korea, Malaysia, Mexico, Peru, the Philippines, Poland, Russia, South Africa, Thailand and Turkey.
} 
decrease in energy intensity, which made them argue that it "might" be associated with the new technologies FDI brings. However, Lee (2013) could not find a significant impact of FDI on $\mathrm{CO}_{2}$ emissions in the G-20 countries. Similarly, focusing on high, middle and low-income countries, Shahbaz et al. (2015) show that FDI increases environmental degradation, confirming the pollution haven-hypothesis ( $\mathrm{PHH})$. Their empirical evidence also shows the presence of a feedback effect between FDI and $\mathrm{CO}_{2}$ emissions, while the findings are sensitive to different income groups and regional effects. In a sectoral level (fishing and agriculture) analysis on OECD countries, Pazienza (2015) indicates that FDI has a negative effect on $\mathrm{CO}_{2}$ emissions. On contrary, in a comprehensive analysis which involved data on 54 countries, ${ }^{5}$ Omri et al. (2014) highlight the existence of a feedback effect between FDI and $\mathrm{CO}_{2}$ emissions, except in Europe and North Asia. Their findings strongly imply that one shall consider the regional-level and country-level heterogeneities, while analysing the nexus between FDI and emissions.

\subsection{Economic Growth-Carbon Emissions Nexus}

Economic growth, often measured as the change in gross domestic product (GDP), has been the most crucial objective of macroeconomic policymaking, particularly in the postWWII capitalist economies (Raworth, 2017) for interesting insight. As consistent growth in GDP is a desirable objective, a frequently raised question is: at what cost? More specifically, what environmental and ecological costs will be paid for economic growth is a concern. A number of studies have endeavoured to answer this question, and one of the most important aspects of the association between economic growth and environmental degradation is the environmental Kuznets curve (EKC). Rooted in the Kuznets curve, presented by Simon Kuznets in 1950s, the EKC suggests an inverted U-shaped relationship between economic growth and environmental degradation. Simply put, it implies that at first, economic growth increases environmental degradation but in the long-run and after reaching a threshold level of real GDP per capita, economic growth decreases environmental degradation.

Analogous to any other economic relationship, the association between economic growth and environmental degradation is rather complex than monotonic, and the existing

\footnotetext{
${ }^{5}$ They include: (a) the European and North Asian regions, consisting of 22 countries, namely: Albania, Belgium, Bulgaria, Denmark, France, Germany, Greece, Hong Kong, Korea, Hungary, Iceland, Ireland, Italy, Japan, Luxembourg, The Netherlands, Norway, Portugal, Spain, Sweden, Switzerland, and the United Kingdom; (b) the Latin American and Caribbean region, consisting of 15 countries, namely: Argentina, Bolivia, Brazil, Chile, Costa Rica, Ecuador, Guatemala, Honduras, Jamaica, Mexico, Panama, Paraguay, Peru, Uruguay, and Venezuela; and (c) the Middle Eastern, North African, and sub-Saharan region, consisting of 17 countries, namely: Algeria, Botswana, Cameroon, Congo, Egypt, Ghana, Iran, Kenya, Morocco, Mozambique, South Africa, Senegal, Sudan, Syrian Arab Republic, Togo, Tunisia, and Zambia.
} 
evidence on the subject offers mixed and inconclusive results. For instance, a study by Apergis (2016) examining the impact of real GDP growth on per capita $\mathrm{CO}_{2}$ emissions in 15 countries reports mixed results. In the majority of countries, there is evidence of the environmental Kuznets curve. Similarly, Onafowora and Owoye's (2014) analysis of Brazil, China, Egypt, Japan, Mexico, Nigeria, South Korea, and South Africa indicates the presence of an EKC only in Japan and South Korea. ${ }^{6}$ They also report that the long-run relationship between economic growth and $\mathrm{CO}_{2}$ emissions follows an $\mathrm{N}$-shaped trajectory, and the estimated turning points are much higher than the sample mean in the rest of 6 countries. This heterogeneity might be associated with the stage of development in each country. In this regard, a study by Narayan and Narayan (2009) on 43 developing countries indicates that for Middle Eastern and South Asian countries (panels), carbon emissions fell with a rise in income. Evidence from other developing economies shows mixed results ${ }^{7}$. This heterogeneity among the developing economies also implies the importance of specific factors that a scholar or a policy maker should take into account when considering the growth-environmental degradation nexus. Nonetheless, these differences are so significant that in large economies such as China and the US, there are also region- and state-level heterogeneities. The studies by Song et al. (2013) on Chinese regions, Apergis (2017) and Atasoy (2017) on the US show mixed results and evidence on the EKC hypothesis, which only holds for some of the regions and states.

At this juncture, the question arises as to whether or not there are differences in the developed versus developing countries. A study by Al-Mulali and Ozturk (2016), using panel data on 27 advanced countries, report an inverted U-shaped relationship between GDP and $\mathrm{CO}_{2}$ emissions. However, any inference should be taken with a grain of salt since there could be differences in the developed countries as well. In terms of comparative analysis, a comprehensive study by Özokcu and Özdemir (2017) on 26 OECD countries with highincome levels as well as 52 emerging countries, show and $\mathrm{N}$-shaped and an inverted $\mathrm{N}$-shaped relationships between economic growth and environmental degradation. This underscores that the results of those authors do not always support the EKC hypothesis, which implies that environmental degradation cannot be solved simply by perpetual economic growth.

Beside the heterogeneities in the results of different countries, the evidence on the

\footnotetext{
${ }^{6}$ The empirical analysis on Korea by Baek and Kim (2013) also reported the existence of the environmental Kuznets curve (EKC).

${ }^{7}$ See for instance, Akbostancı et al. (2009) and Bölük and Mert (2015) on Turkey, Fodha and Zaghdoud (2010) on Tunisia, Nasir and Rehman (2011) and Shahbaz et al. (2012) on Pakistan, Saboori et al. (2012) on Malaysia, Al-Mulali et al. (2015) analysis on Vietnam, Shahbaz et al. (2013) on Romania, Robalino-López et al. (2015) on Venezuela,
} 
EKC in a single country is also sometimes contradicting. For instance, a study on Spain by Esteve and Tamarit (2012) shows that the long-run elasticity estimates of per-capita $\mathrm{CO}_{2}$ emissions and per-capita income show a tendency to decrease over time. Hence, as the "income elasticity" is less than one, it implies that even if the shape of the EKC does not follow an inverted-U, it shows a decreasing growth path, pointing to the prospective turning point. On the other hand, Sephton and Mann (2013) reveal that there is a long-run non-linear attractor that draws per capita income and $\mathrm{CO}_{2}$ emissions levels together, with asymmetric adjustment in Spain. In contrasting evidence from India, Ghosh (2010) fails to establish a long-run equilibrium relationship and long-run causality between economic growth and carbon emissions, but in the short-run, a feedback effect exists between the variables. Similarly, Tiwari et al. (2013) underline the presence of EKC in the long run as well as in the short run. However, the recent evidence from India and China by Pal and Mitra (2017) shows an $\mathrm{N}$-shaped relationship between economic activity and $\mathrm{CO}_{2}$ emissions, which is a departure from the EKC hypothesis.

In the case of France, Ang (2007) underlines the positive effect of economic growth on energy usage and $\mathrm{CO}_{2}$ emissions. However, he did not look at the inverting relation (as just employed the VECM model), which is an important factor to take into account. The consideration of long-run consequences and the choice of an appropriate methodological approach is also vital in this context. Fosten et al. (2015) analyze the UK economy ${ }^{8}$, and their findings show that not only does the inverted-U shaped hold between $\mathrm{CO}_{2}$ (and $\mathrm{SO}_{2}$ ) emissions per capita and GDP per capita, but they also find that the temporary disequilibrium resulting from the long-run EKC is corrected in an asymmetric fashion. They argue that it could be associated with the historical pressure of environmental regulations in the UK to reduce emissions that are higher than permitted. Therefore, their analysis suggests that the technological change can also partially account for the asymmetric adjustment, which is also an aspect considered in this study.

\subsection{Financial Development-Carbon Emissions Nexus}

A vibrant financial sector is important for economic growth and development of a country; however, it is also important to take into account the environmental and ecological implications of financial development. A financial sector which enhances economic growth can intuitively lead to an increase in energy consumption (Sadorsky 2009, 2011; Shahbaz et al 2012; Shahbaz et al. 2013; Islam et al. 2013; Shahbaz et al. 2017 among others). However, the

\footnotetext{
${ }^{8}$ The UK economy is similar to France in terms of size.
} 
evidence concerning the nexus between financial development and carbon emissions is mixed and can be easily categorised into the following strands. The first strand of the literature suggests a negative impact of financial development on environmental degradation, mainly $\mathrm{CO}_{2}$ emissions. One of the pioneering studies (Tamazian et al., 2009) on the impact of financial development on carbon emissions in BRICS countries finds that economic growth and financial development reduce $\mathrm{CO}_{2}$ emissions. Later, Tamazian and Rao (2010) focused on financial liberalisation (which is not the same as financial development) in 24 transition economies. They argue that financial development plays an important role in improving environmental quality by lowering $\mathrm{CO}_{2}$ emissions. The empirical evidence from China reached by Jalil and Feridun (2011) show a negative and significant impact of financial development on $\mathrm{CO}_{2}$ emissions. Those authors' results suggest that financial development improves environmental quality by lowering carbon emissions in China. Shahbaz et al. (2013) contend that financial development reduces $\mathrm{CO}_{2}$ emissions in Malaysia. Similarly, Shahbaz et al. (2013) show negative effects of financial development on $\mathrm{CO}_{2}$ emissions in South Africa. Abbasi and Riaz (2016) examine the relationship between financial development and carbon emissions in Pakistan and report that financial variables play a role in emissions mitigation, but only in the period of a greater degree of liberalization and financial sector development. Dogan and Seker (2016), using panel data from top countries listed in the renewable energy attractiveness index, indicate that financial development improves environmental quality by lowering $\mathrm{CO}_{2}$ emissions.

The second strand of literature suggests a positive effect of financial development on carbon emissions. For instance, a study by Zhan (2011) on China shows that financial development is an important driver of $\mathrm{CO}_{2}$ emissions. Similarly, Shahbaz et al. (2013) underscore the positive and significant effect of financial development on $\mathrm{CO}_{2}$ emissions in Indonesia. Later, by employing a comprehensive index of financial developments using bankbased and stock market-based financial development indicators, Shahbaz et al. (2016) show that only the bank-based financial development impedes environmental quality by increasing carbon emissions. Javid and Sharif (2016) report that financial development adds to carbon emissions in Pakistan. In a recent study on FDI, Salahuddin et al. (2018) reveal a positive and significant effect of FDI and financial development on $\mathrm{CO}_{2}$ emissions in Kuwait.

The third strand of literature is the one which does not provide a significant evidence on the nexus between financial development and environmental degradation. For instance, Ozturk and Acaravci (2013) argue that financial development has no significant effect on carbon emissions in the long-run in the Turkish economy. Similarly, Omri et al. (2015) report 
a neutral effect of financial development on carbon emissions for 12 MENA countries. There are also some multi-country studies, for instance, Bekhet et al. (2017) which suggest mixed results for the six GCC countries. Specifically, this study indicates that financial development tends to increase carbon emissions in Saudi Arabia, Oman, Kuwait and Bahrain, but decreases $\mathrm{CO}_{2}$ emissions in the UAE and Qatar. While specifically focusing on the UAE, Charfeddine and Khediri (2016) report an inverted-U shaped relationship between financial development and $\mathrm{CO}_{2}$ emissions. Some of the studies in developed countries also show mixed and neutral results. For instance, Çoban and Topcu (2013) analyze the relationship between financial development and carbon emissions in the EU-27 countries. They report a neutral relationship between financial development and energy consumption. Specifically, while using the bank index, their results suggest that the impact of financial development displays an inverted-U shaped pattern between the variables, while no significant relationship is detected once it is measured using the stock index. They imply that while the measurement is important, there are also significant country-level heterogeneities in the effects of financial development.

\subsection{Energy Research Innovations and Carbon Emissions Nexus}

The importance of technological innovations is paramount to the production process as well as to economic growth (Andersson et al., 2011; Çalışkan, 2015). Technological innovations have considerable effects on the association among economic entities. This is manifested in Schumpeter (1942)'s notion of "Creative Destruction", which is an evolutionary process involving the destruction of the inefficient and weak sectors of the economy as well as development of new technologies and new industries (see Çalışkan, 2015 for discussion). By the same token, technological innovations have environmental consequences. It is logical to argue that a technological innovation leading to structural changes in production process shall also influence the environment. According to Grossman and Krueger, (1991), technology is an important channel through which economic growth impacts environmental degradation. Due to this impact, a number of studies have urged employing technologies which can improve environmental quality (Dinda, 2004; Brock and Taylor, 2005). Progress leads to the creation of cleaner and ecologically sustainable technologies (Hussen, 2005). This profound importance of the technological process is manifested in the Balsalobre-Lorente (2018, P. 358) argument which states "When the total effect of the relationship between economic growth and environmental pollution is dissected, the technical effect is the main factor in environmental pollution reduction".

Motivated by the importance of technology in environmental degradation a number of 
empirical studies analyze the nexus between the two factors. For instance, a study by Tang and Tan (2013) reports a significant relationship between electricity consumption, economic growth, and technological innovations. ${ }^{9}$ It led them to infer that technological innovations play an important role in mitigating the use of fossil fuels. Their findings are complemented by a later study by Fei et al. (2014), which also confirms the importance of technological innovation to environmental degradation in New Zealand and Norway. In a similar vein, a number of other studies also reflect the importance of technology in mitigating environmental degradation and ecological challenges (see, for instance, Arrow et al., 1996; Torras and Boyce, 1998; Andreoni and Levinson, 2001; Lorente and ÁlvarezHerránz, 2016; and ÁlvarezHerránz et al., 2017).

The importance of technological factors in mitigating environmental degradation also implies that efforts shall be made to avoid the obsolescence of technology, which is very often done via regulation of technological development (Bruvoll et al., 2003; Turner and Hanley, 2011; and Álvarez-Herránz et al., 2017). However, one under-appreciated aspect of this which has profound implications for policy-making is investment in energy innovations. It is intuitively acknowledged and evident by earlier cited studies that innovations, in general, are important for environmental degradation, and therefore, innovations in the energy sector would have rather direct implications.

\subsection{Empirical Model}

This study examines the relationship between FDI and $\mathrm{CO}_{2}$ emissions while incorporating economic growth, financial development and energy research innovations in a French carbon emissions function. The existing evidence suggests that FDI may affect carbon emissions via scale, technique, and composition effects. The scale effect states that foreign direct investment may increase $\mathrm{CO}_{2}$ emissions via influence on economic activity as a result of economic liberalization. Economic liberalization leads to more production, which increases energy consumption and, hence, affects environmental quality by increasing carbon emissions (Stern, 2004; Pazienza, 2015). Shahbaz et al. (2015) argue that the relationship between FDI and carbon emissions depends upon the association between FDI and economic growth.

The technique effect captures the impact of the transfer and diffusion of new technology as well as the introduction of new environmental regulation on environmental quality. FDI induces the implementation of advanced and energy-efficient technology to

\footnotetext{
${ }^{9}$ This is the manifestation of the applicability of endogenous growth theory to the energy sector.
} 
enhance domestic production. It implies that the technique effect may affect environmental quality through the introduction, development, and diffusion of advanced and energy efficient technology. This indicates that energy efficient technologies are the cause of more stringent environmental regulations meant to improve environmental quality by declining carbon emissions' intensity (Pazienza, 2015b). The composition effect is related to the structural shift of an economy from agriculture to industrial and from industrial to services sectors. The former (industrial) consumes more energy compared to the latter. The impact of the composition effect depends upon the competitive advantages and productive specialization of the economy (Cole and Elliott, 2003).

Financial development may affect carbon emissions via consumer, business, and wealth effects. A sound financial system benefits consumers by providing them access to loans for buying big-ticket items, such as houses, automobiles, refrigerators, air conditioners, and washing machines, which of course affects energy demand and, hence, impacts environmental quality (Chang, 2015; Mahalik et al., 2017). The business effect demonstrates that the financial system channels financial resources to their destinations by offering loans to firms at a lower interest rate, boosting investment opportunities. The financial development also helps firms enhance their existing and new investment endeavours, which increases energy demand and impedes environmental quality by raising carbon emissions (Mahalik et al., 2017). Growth effect indicates that financial development boosts economic activity by encouraging investment activities, which increases per capita income, resulting in a higher energy consumption and carbon emissions as well (Chang, 2015; Mahalik et al., 2017). Research and development expenditures in the energy sector induce energy innovations, which lowers energy intensity and improves environmental quality by lowering carbon emissions (Komen et al. 1997; Balsalobre-Lorente et al., 2018).

Following the above theoretical background, we model the general carbon emissions function as:

$$
C_{t}=f\left(I_{t}, Y_{t}, E_{t}, F_{t}, R_{t}\right)
$$

where $C_{t}, I_{t}, Y_{t}, E_{t}, F_{t}, R_{t}$ and $\varepsilon_{i}$ are per capita $\mathrm{CO}_{2}$ emissions, real FDI per capita, real GDP per capita, energy consumption per capita, real domestic credit to the private sector per capita and real research and development expenditures for energy innovations. We have transformed all the variables into natural-log for employing a log-linear specification rather than the linear 
specification of the empirical model. It is argued by Shahbaz et al. (2012) that the log-linear specification provides consistent and reliable empirical results, comparative to the linear case. The log-linear empirical model provides direct estimates of elasticities since they are the coefficient of explanatory variables. The log-linear specification of carbon emissions function is modelled as follows:

$$
\ln C_{t}=\beta_{0}+\ln \beta_{1} I_{t}+\ln \beta_{2} Y_{t}+\ln \beta_{3} E_{t}+\ln \beta_{4} F_{t}+\ln \beta_{5} R_{t}+\varepsilon_{i}
$$

where the variables are the natural logs of those in Eq. (1) and the error term is assumed to be normally distributed.

We also investigate whether the relationship between FDI per capita and carbon emissions per capita has an inverted-U shaped or a U-shaped following Shahbaz et al. (2015). In doing so, we include a squared term of FDI per capita into the carbon emissions function. Similarly, we also include squared terms of real GDP per capita and domestic credit to the private sector into the carbon emissions function to examine whether the relationship between carbon emissions per capita and economic growth and between carbon emissions per capita and financial development is inverted-U shaped or U-shaped. The augmented carbon emissions function with the squared terms of FDI per capita, economic growth and financial development are modelled as following:

$$
\begin{aligned}
\ln C_{t}= & \alpha_{0}+\ln \alpha_{1} I_{t}+\ln \alpha_{2} I_{t}^{2}+\ln \alpha_{3} Y_{t}+\ln \alpha_{4} Y_{t}^{2}+\ln \alpha_{5} E_{t} \\
& +\ln \alpha_{6} F_{t}+\ln \alpha_{7} F_{t}^{2}+\ln \alpha_{8} R_{t}+\varepsilon_{i}
\end{aligned}
$$

The relationship between FDI per capita and carbon emissions per capita is inverted U-shaped if $\alpha_{1}>0$ and $\alpha_{2}<0$; otherwise, it is U-shaped if $\alpha_{1}<0$ and $\alpha_{2}>0$. The inverted U-shaped relationship indicates that FDI per capita is initially accompanied by carbon emissions per capita, but the carbon emissions start to decline after a certain level of FDI per capita, representing the shape of the environment Kuznets curve hypothesis (Shahbaz et al., 2015) and vice versa. Similarly, $\alpha_{3}>0$ and $\alpha_{4}<0$ points to an inverted-U shaped association between economic growth and carbon emissions, while the relationship between the variables is Ushaped if $\alpha_{3}<0$ and $\alpha_{4}>0$. The inverted-U relationship between financial development and carbon emissions prevails if $\alpha_{6}>0$ and $\alpha_{7}<0$; otherwise it is $\mathrm{U}$-shaped. 


\subsection{Data}

In this study, we employ the time-series data spanning over 62 years from 1955-2016. The data on $\mathrm{CO}_{2}$ emissions per capita (metric ton), real GDP per capita (constant local currency), real FDI per capita (constant local currency), energy consumption ( $\mathrm{kg}$ of oil equivalent) and real domestic credit to private sector (constant local currency) are collected from the World Development Indicators (2018). The data on public budget in energy research and development expenditures (constant local currency) are collected from the European Commission's database. ${ }^{10}$ The data on total population collected from the World Development Indicators (CD-ROM, 2018) are used to convert all the variables into per capita units. This has benefits in terms of standardisation as well as ease of comparison (unit of measurement) and latter discussion and drawl of inferences. We also used real estimated i.e. adjusted for inflation.

\section{Methodological Framework}

\subsection{SOR Unit Root Test with Sharp \& Smooth Breaks}

In order to examine the integrating properties of the variables, we apply the sharp and smooth structural breaks unit root test developed by Shahbaz, Omay and Roubaud (hereafter SOR, 2017). The novelty of SOR unit root test is that it is nonlinear-unit root test, which accounts for sharp and smooth structural breaks in the time series. It is very important to account for the structural break as a unit root test ignores the structural break can yield the biased estimates (Nasir et al. 2017). For instance, classical unit root tests such as Augmented DickeyFuller (ADF) and Phillips-Perron (PP) overlook the presence of nonlinearity and structural breaks in the series which may be potential cause of unit root problem. These unit root tests accept null hypothesis when it is false and vice versa due to their low explanatory power and present ambiguous results. In such circumstances, SOR unit root test is suitable test compared to ADF and PP tests which solves the issue of nonlinearity with sharp and smooth structural breaks in the series and provides consistent and reliable empirical results. Following the empirical foundations laid by Leybourne et al. (1998), the SOR test entails a two-step approach which is as follows:

\footnotetext{
10 The Europa- Strategic Energy Technologies Information System, can be accessed via,
} https://setis.ec.europa.eu 
Step 1. The constrained nonlinear optimization algorithm via Genetic is used. ${ }^{11}$ Thereafter, the deterministic component of the preferred model is estimated, and its residuals are computed by using model A, B and C as given in the following model 4, 5 and 6 :

$$
\begin{aligned}
& \text { Model A: } \hat{\varepsilon}_{t}=y_{t}-\hat{\alpha}_{1}-\hat{\alpha}_{2} F_{t}(\hat{\gamma}, \hat{\tau}) \\
& \text { ModelB : } \hat{\varepsilon}_{t}=y_{t}-\hat{\alpha}_{1}+\hat{\beta}_{1} t-\hat{\alpha}_{2} F_{t}(\hat{\gamma}, \hat{\tau}) \\
& \text { ModelC: } \hat{\varepsilon}_{t}=y_{t}-\hat{\alpha}_{1}-\hat{\beta}_{1} t-\hat{\alpha}_{2} F_{t}(\hat{\gamma}, \hat{\tau})-\hat{\beta}_{2} F_{t}(\hat{\gamma}, \hat{\tau}) t
\end{aligned}
$$

Step 2. This step involves computing the Enders and Lee test statistic, hereafter, the EL (2012) test statistic, which is actually the $t$-ratio associated with $\hat{\phi}$ in the ordinary least squares regression:

$$
\hat{\varepsilon}_{t}=d(t)+\phi_{1} \hat{\varepsilon}_{t-1}+v_{t}
$$

where $d(t)$ is a deterministic function of $t$, and $v_{t}$ is a stationary disturbance with variance $\sigma^{2}$ - A point to note here is that $\varepsilon_{t}$ is weakly dependent, and the initial value is assumed to be fixed. It is possible to estimate Equation (7) directly and to test the null hypothesis of a unit root (i.e. $\left.\phi_{1}=1\right)$ if the functional form of $d(t)$ is known. However, we do not know the form of $d(t)$; in that case, any testing could be problematic for $\phi_{1}=1$ if $d(t)$ is mis-specified. Yet, the approach chosen in this study is based on the theory that it is conventionality possible to approximate $d(t)$ using the Fourier expansion:

$$
d(t)=\alpha_{0}+\sum_{k=1}^{n} \alpha_{k} \sin \left(\frac{2 \pi k t}{T}\right)+\sum_{k=1}^{n} \beta_{k} \cos \left(\frac{2 \pi k t}{T}\right), n \leq T / 2
$$

where the number of cumulative frequencies contained in the approximation are represented by $n, \mathrm{k}$ depicts a specific frequency, and the number of observations are presented by $T$. In

\footnotetext{
${ }^{11}$ We use the genetic algorithm in our estimation process of the smooth transition trend since it is shown to be the best performing algorithm in estimating the LST types of equations. For details, see Omay and Emirmahmutoglu (2017).
} 
this case, we don't have a nonlinear trend for all the values of $\alpha_{k}=\beta_{k}=0$, hence, the LNV (1998) specification becomes a special case. It will not be advisable to use a large value of $n$ for a number of good reasons. We will demonstrate this phenomenon; however, the main issue is that it can lead to a problem of over-fitting, as the presence of many frequency components consumes the degrees of freedom.

A number of remarkable studies, for instance, Gallant (1981), Davies (1987), Gallant and Souza (1991), and Bierens (1997), empirically show that with a small number of frequency components, we can often capture the essential characteristics of an unknown functional form smooth break while employing the Fourier approximation. Furthermore, as it is vital to accommodate the evolution of the nonlinear trend to be gradual, hence, $n$ should be small. ${ }^{12}$ Nonetheless, the notion that the series may revert to an arbitrarily evolving mean does not hold much water. Finally, the testing equation can be presented in the following form:

$$
\Delta \hat{\varepsilon}_{t}=\alpha_{0}+\sum_{k=1}^{n} \alpha_{k} \sin \left(\frac{2 \pi k t}{T}\right)+\sum_{k=1}^{n} \beta_{k} \cos \left(\frac{2 \pi k t}{T}\right)+\phi_{1} \hat{\varepsilon}_{t-1}+\sum_{i=1}^{p} \varphi_{k} \Delta \hat{\varepsilon}_{t-i}+v_{t}
$$

To account for any stationary dynamics in $\hat{\varepsilon}_{t}$, it is a common practice to augment the dependent variables' lag value in testing the equation. Concomitantly, the value of the EL test statistic is depicted as $s \tau_{\alpha}$ in Model A and is used to construct $\hat{\varepsilon}_{t}, s \tau_{\alpha(\beta)}$ if we used Model B, and $s \tau_{\alpha, \beta}$ in the case of Model C. In the SOR unit root test, an important issue to keep an eye on is whether a small number of frequency components would be able to replicate the types of breaks often observed in economic data. In order to keep track of this aspect, we started with a Fourier approximation employing a single frequency component so that the single frequency selected for the approximation is depicted by $\mathrm{k}$, while the amplitude and displacement of the sinusoidal component of the deterministic term is measured by $\alpha_{k}$ and $\beta_{k}$. Therefore, we are able to allow for multiple smooth breaks even with a single frequency $\mathrm{k}=1$.

We can state the hypotheses of unit root testing based on models $\mathrm{A}, \mathrm{B}$, and $\mathrm{C}$ with the Fourier transformation in the following form:

\footnotetext{
12 Becker et al. (2006) indicated that structural change can be captured by the relatively low frequency components of a series since breaks shift the spectral density function towards zero. Becker et al (2006). also show that the higher frequency components of a series are most likely to be associated with stochastic parameter variation. When the sample size gets very large, it will be natural to expect that the number of frequencies (n) will also increase accordingly. In the limit, we may let $n=n(T) \rightarrow \infty$ as $T \rightarrow \infty$. However, as $n$ increases, the tests lose power. As such, in finite samples, it is sufficient to treat $\mathrm{n}$ as a finite value (n_T), and the test depends on $\mathrm{n}$.
} 
$H_{0}:$ Unit Root (Linear Nonstationary)

$H_{1}:$ Nonlinear Stationary $\left(\begin{array}{l}\text { Nonlinear and Stationary around } \\ \text { simultenously changing sharp and smooth trend }\end{array}\right)$

To test the hypothesis against the critical values, we will draw on critical values of the SOR unit root test for Model A* provided by Shahbaz et al. (2017) ${ }^{13}$.

\subsection{The Bootstrapping ARDL Bounds Testing Approach to Cointegration}

In order to analyze the cointegration relationship between the variables, we consider the bootstrapping ARDL cointegration approach recently introduced by McNown et al. (2018). The novelty of the bootstrapping ARDL approach is that it addresses the issue of weak size and power properties encountered in the conventional ARDL approach developed by Pesaran and Shin (1999) and, later on, Pesaran et al. (2001). Furthermore, in order to increase the power of the t-test and the F-test, this approach has the ability to integrate a new test to draw on and add to the conventional ARDL bounds testing approach framework.

In order to decide the existence of cointegration between the variables without using the Pesaran et al. (2001) approach, we need to do three tests. Pesaran et al. (2001) only require two conditions for the identification of cointegration: a) the coefficients of the errorcorrection terms are required to be statistically significant and b) the coefficients of the lagged explanatory variables are also required to be statistically significant (Pesaran et al. 2001). However, the first condition only holds when the lagged dependent variable is statistically significant in the error-correction term, yet the second condition only holds if the lagged explanatory variables are statistically significant. In his seminal work, Pesaran et al. (2001) suggest that at this juncture, one shall use the critical bounds (upper and lower bounds) for the second case, yet for the first case, there is no bound test or critical bounds. In the first scenario, if the coefficients of the error-correction terms are statistically significant, the test can be used if all the variables in the model first are differenced stationary, i.e. integrated of order 1. However, one important factor to consider is that the conventional unit root tests

\footnotetext{
${ }^{13}$ They argue that for the newly proposed test with trends in the Fourier function critical values are not tabulated because Model B and C of the LNV type of trend already consist of trend functions. Therefore, including trends in the second step is useless. However, we include the trend in the Fourier function for Model-A because there is no trend variable in Model A of the smooth transition trend. This model is probably a competitor of Model B. Additionally, we do not generate the critical values for the cumulative Fourier function because the LNV function captures the sharp breaks without including any other terms.
} 
could be problematic due to the low explanatory and power properties they possess (see Goh et al., 2017). This issue can be solved by employing the bootstrapping ARDL test of McNown et al. (2018) and using the new test statistics. The bootstrapping critical values have a larger size and power properties as also shown by the Monte Carlo simulations.

A novelty of the bootstrapping ARDL bounds testing approach is that it is not sensitive to the order of integration properties of the variables and is also suitable for dynamic time-series models, small sample data (Goh et al., 2017). Concomitantly, one of the significant features of this approach is that it conveniently handles the issue of inconclusive cases, which may arise while using the conventional ARDL bounds testing approach (McNown et al., 2018). ${ }^{14}$ Nonetheless, given the fact that upper and lower critical bounds defined in the conventional ARDL bounds test approach are based on the data-generating process if all the regressors are integrated at $\mathrm{I}(0)$ or $\mathrm{I}(1)$. Further, critical bounds tabulated by Pesaran et al. (2001), which are appropriate for long span data samples, could lead to an inconclusive outcome (Narayan, 2005). On the other hand, critical values are generated in the bootstrap ARDL testing procedure by eliminating the possibility of indecision cases, which occur in the traditional bounds testing approach.

Another benefit of employing bootstrapping ARDL bounds testing is that it is useful for dynamic models with more than one explanatory variable. Seemingly trivial, an important factor to consider is that the critical value bounds proposed by Pesaran et al. (2001) came with the assumption of a strict exogeneity of the explanatory variables. Yet, in the real world, the strict exogeneity condition does not hold very often, particularly in the macroeconomic relationships. The traditional and bootstrapping ARDL bounds testing procedure can be mathematically specified. Following Goh et al. (2017, P. 14), let's consider an ARDL (p, q, r), model with three variables:

$$
y_{t}=\sum_{i=1}^{p} \alpha_{i}^{\prime} y_{t-i}+\sum_{j=0}^{q} \beta_{J}^{\prime} x_{t-j}+\sum_{k=0}^{r} \gamma_{k}^{\prime} z_{t-k}+\sum_{i=1}^{s} \tau_{l}^{\prime} D_{t, l}+\mu_{t}
$$

where $i, j, k$, and $l$ denote the lags $(i=1,2 \ldots \mathrm{p} ; j=0,1,2, \ldots, \mathrm{q} ; k=0,1,2, \ldots . \mathrm{r} ; l=0$, $1,2, \ldots \mathrm{s}$; and $t$ represents the time, $y_{t}$ is the response variable, and $x_{t}$ and $z_{t}$ are the explanatory variables. $D_{t, l}$ is the dummy variable, $\beta$ and $\gamma$ represent the coefficients of the lagged explanatory variables, and $\tau$ is the coefficient of dummy variable. Finally, $\mu_{t}$

\footnotetext{
${ }^{14}$ It is well-known that the traditional ARDL bounds testing approach can successfully be applied to empirical models if the variables have mixed order of integration.
} 
represents the error-term with zero mean and finite variance. This same model can be specified in an error correction form as follows:

$$
\begin{aligned}
\Delta y_{t}= & \phi y_{t-1}+\gamma x_{t-1}+\psi z_{t-1}+\sum_{i=1}^{p-1} \lambda_{i}^{\prime} \Delta y_{t-i}+\sum_{j=1}^{q-1} \delta_{J}^{\prime} \Delta x_{t-j}+\sum_{k=1}^{r-1} \pi_{k}^{\prime} \Delta z_{t-k}+ \\
& \sum_{i=1}^{s} \omega_{l}^{\prime} D_{t, l}+\varepsilon_{t}
\end{aligned}
$$

In Equation (12), $\phi=\sum_{i=1}^{p} \alpha_{i}, \gamma=\sum_{j=0}^{q} \beta_{J}$, and $\psi=\sum_{k=0}^{r} \gamma_{k}$. At this point, $\lambda_{i}, \delta_{J}$, $\pi_{k}$, and $\omega_{l}$ account for the associated functions in Equation (1). By transforming the vector auto-regression in the levels into its error-correction form, the derivation of Equation (11) from Equation (12) is estimated. Whereas Equation (11) can be estimated by using the constant term $(\tilde{c})$ in the unconditional model that can be specified as:

$$
\begin{gathered}
\Delta y_{t}= \\
\tilde{c}+\tilde{\phi} y_{t-1}+\tilde{\gamma} x_{t-1}+\tilde{\psi} z_{t-1}+\sum_{i=1}^{p-1} \tilde{\lambda}_{i}^{\prime} \Delta y_{t-i}+\sum_{j=1}^{q-1} \tilde{\delta}_{J}^{\prime} \Delta x_{t-j}+ \\
\sum_{k=1}^{r-1} \tilde{\pi}_{k}^{\prime} \Delta z_{t-k}+\sum_{i=1}^{s} \widetilde{\omega}_{l}^{\prime} D_{t, l}+\tilde{\varepsilon}_{t}
\end{gathered}
$$

It requires the rejection of all three null hypothesis to confirm the cointegration among the variables $y_{t}, x_{t}$, and $z_{t}$.

The hypothesis can be stated as:

i) The $\mathrm{F}_{1}$ test which is based on all of the relevant error-correction terms $\left(\mathrm{H}_{0}: \phi=\gamma=\psi=0\right.$ against $\mathrm{H}_{1}$ : any of $\phi, \gamma, \psi$ are different from zero),

ii) The $\mathrm{F}_{2}$ test which is based on all of the explanatory variables terms $\left(\mathrm{H}_{0}: \gamma=\psi=0\right.$ against $\mathrm{H}_{1}$ : either $\gamma$ or $\psi$ is different from zero),

iii) The t-test which is based on the lagged dependent variable $\left(\mathrm{H}_{0}: \phi=0\right.$ against $\mathrm{H}_{1}: \phi$ is different from zero).

A point to note here is that only the critical values of the bounds test for the $F_{1}$ and $t-$ tests are generated in the traditional ARDL approach, yet it ignores the test statistic for the $\mathrm{F}_{2}$ test on the lagged explanatory variables. However, employing the bootstrapping ARDL approach proposed by McNown et al. (2018) can provide the critical values for all three tests. Concurrently, in our endeavor to provide the empirically robust results, in this study we employed the critical values tabulated by McNown et al. (2018). 


\section{Empirical Findings and Discussion}

To begin, we perform the descriptive statics and the pair-wise correlation, and the results are presented in Table-1. Table-1 shows that $\mathrm{CO}_{2}$ emissions are less volatile than economic growth. The volatility in energy consumption is higher compared to $\mathrm{CO}_{2}$ emissions, but lower than economic growth. FDI is highly volatile compared to financial development. The volatility in public budget in energy research and development expenditures is higher compared to $\mathrm{CO}_{2}$ emissions, energy consumption, and economic growth, but less than FDI and financial development.

The correlation analysis reveals a positive correlation between economic growth and $\mathrm{CO}_{2}$ emissions. Energy consumption and FDI are positively correlated with $\mathrm{CO}_{2}$ emissions. The correlation of financial development and public budget in energy research and development expenditures (energy innovations) with $\mathrm{CO}_{2}$ emissions is negative. Energy consumption, financial development, FDI, and public budget in energy research and development expenditures are positively correlated with economic growth. The correlation of FDI and public budget in energy research and development expenditures with financial development is positive. A positive correlation also exists between public budget in energy research and development expenditures and FDI.

Table-1: Descriptive Statistics and Pair-wise Correlation Analysis (1955-2016)

\begin{tabular}{|l|c|c|c|c|c|c|}
\hline Variable & $\ln C_{t}$ & $\ln Y_{t}$ & $\ln E_{t}$ & $\ln F_{t}$ & $\ln I_{t}$ & $\ln R_{t}$ \\
\hline Mean & 1.8711 & 10.1805 & 8.0462 & 11.7760 & 4.7118 & 3.4079 \\
\hline Median & 1.8316 & 10.2641 & 8.1902 & 12.2703 & 4.0628 & 3.5551 \\
\hline Maximum & 2.2686 & 10.6457 & 8.3667 & 12.9240 & 7.2065 & 4.1776 \\
\hline Minimum & 1.4634 & 9.1897 & 7.1099 & 4.9977 & 2.3042 & 1.7409 \\
\hline Std. Dev. & 0.2095 & 0.4215 & 0.3417 & 1.3220 & 1.5199 & 0.6068 \\
\hline Skewness & 0.1662 & -0.7698 & -1.2867 & -2.4323 & 0.1349 & -0.8708 \\
\hline Kurtosis & 2.3530 & 2.4646 & 3.4689 & 12.1367 & 1.4844 & 3.0368 \\
\hline Jarque-Bera & 1.3667 & 1.8655 & 1.67742 & 1.5910 & 1.1219 & 1.8393 \\
\hline Probability & 0.5049 & 0.2032 & 0.2245 & 0.2657 & 0.6084 & 0.2108 \\
\hline $\ln C_{t}$ & 1.0000 & & & & & \\
\hline $\ln Y_{t}$ & 0.1160 & 1.0000 & & & & \\
\hline $\ln E_{t}$ & 0.4245 & 0.3622 & 1.0000 & & & \\
\hline $\ln F_{t}$ & -0.1978 & 0.5528 & 0.5160 & 1.0000 & & \\
\hline $\ln I_{t}$ & 0.5908 & 0.4897 & 0.4511 & 0.5378 & 1.0000 & \\
\hline $\ln R_{t}$ & -0.10835 & 0.4036 & 0.3519 & 0.4475 & 0.5575 & 1.0000 \\
\hline
\end{tabular}


In order to examine the unit root properties of the variables, we have applied the augmented Dickey-Fuller (ADF) unit root test without and with structural breaks in the series. The results are reported in Table-2. We note that carbon emissions, FDI, economic growth, energy consumption, financial development and research and development expenditures show a presence of stochastic unit root process in the level with intercept and trend. All the variables are found stationary after first difference. This shows that all the variables are integrated of I(1). The ADF unit root test is a traditional test which has some criticisms. For instance, this test may produce vague empirical results as it is unable to capture the information for unknown structural breaks that are embodied in the series. The presence of structural breaks may be a cause of the unit root problem in time series. Due to this problem, the ADF unit root test may reject the null hypothesis when it is true, and vice-versa. This issue is solved by applying the ADF test that considers structural breaks in the series, which is developed by Kim and Perron (2009). The results are shown in Table-2. We note that carbon emissions, FDI, economic growth and energy consumption have a unit root in the presence of structural breaks in the series, but financial development and research and development expenditures are found stationary in the level. These structural breaks seem to be the outcome of structural reforms such as economic, energy, environmental, and financial reforms implemented over the study period to improve sustainable environmental quality in order to achieve long-run economic development. The break years are 1979, 1986, 2008, 1968, and 2014 for carbon emissions, FDI, economic growth, energy consumption, financial development, and research and development expenditures respectively. At the first difference, carbon emissions, FDI, economic growth, and energy consumption become stationary i.e. I(1). This underscores the presence of a mixed order of integration of the variables, i.e. $\mathrm{I}(0) / \mathrm{I}(1)$.

Table-2: Unit Root Analysis (1955-2016)

\begin{tabular}{|l|c|c|c|c|c|}
\hline \multirow{2}{*}{ Variable } & \multicolumn{2}{|c|}{ ADF Test at Level } & \multicolumn{3}{c|}{ Kim-Perron ADF Test at Level } \\
\cline { 2 - 6 } & T- Statistic & P. Value & T- Statistic & P. Value & Break Year \\
\hline $\ln C_{t}$ & -2.7900 & 0.2056 & -3.0780 & 0.8871 & 1979 \\
\hline $\ln Y_{t}$ & -2.5879 & 0.2867 & -3.5124 & 0.6851 & 2008 \\
\hline $\ln E_{t}$ & -1.7080 & 0.7358 & -2.7373 & 0.9625 & 1968 \\
\hline $\ln F_{t}$ & -2.8190 & 0.2233 & -6.8891 & 0.0001 & 1979 \\
\hline $\ln I_{t}$ & -2.1323 & 0.5174 & -3.2460 & 0.9117 & 1986 \\
\hline $\ln R_{t}$ & -2.6877 & 0.2457 & -7.6234 & 0.0001 & 2014 \\
\hline \multicolumn{7}{|c}{ SOR Sharp-Smooth Structural Break Test } \\
\hline Variable & T-statistic & $\bar{a}_{2}$ & T & $\bar{\gamma}$ & $\alpha_{k}$ \\
\hline
\end{tabular}




\begin{tabular}{|l|c|c|c|c|c|}
\hline $\ln C_{t}$ & -4.3710 & 2.4967 & -1.1255 & -0.2586 & -0.1260 \\
\hline $\ln Y_{t}$ & -2.5944 & 10.7783 & -1.3033 & 243.9143 & -0.6967 \\
\hline $\ln E_{t}$ & -2.3235 & 8.6026 & -1.0633 & 201.5062 & -1.5669 \\
\hline $\ln F_{t}$ & $-5.8728^{*}$ & 9.6711 & -1.4389 & 0.2361 & 0.7703 \\
\hline $\ln I_{t}$ & -3.9358 & 17.2983 & -13.5937 & -0.1030 & 0.5445 \\
\hline $\ln R_{t}$ & $-4.8053^{*}$ & 2.3947 & -7.6792 & -4.1551 & -1.0414 \\
\hline
\end{tabular}

Note: The critical t-values at $1 \%, 5 \%$ and $10 \%$ are $-5.415,-4.740$ and -4.408 , respectively.

In order to test the robustness of the unit root analysis, we have also applied the SOR (2017) unit root test which accounts for the sharp and smooth breaks. The empirical results of the SOR (forthcoming) unit root are reported in the lower segment of Table-2. The results noted in Table- 2 reveal that the null hypothesis of the unit root may not be rejected for financial development and public budget in energy research and development expenditures, as the calculated t-statistics are less than the critical t-values generated by Shahbaz et al. (2017). Further, the empirical results show that carbon emissions, FDI, economic growth and energy consumption contain unit root processes. The information of nonlinear parameters estimated in Model $\mathrm{A}^{*}$ validated the presence of sharp and smooth breaks in the series. ${ }^{15}$ This implies that financial development and public budget in energy research and development expenditures are integrated of $\mathrm{I}(0)$, and the rest of the variables are stationary after first differencing i.e. $\mathrm{I}(1)^{16}$. It corroborates the robustness of the unit root analysis as the SOR unit root test validates the results provided by Kim-Perron (2009)'s ADF unit root test. We may conclude that all the variables in carbon emissions contain a mixed order of integration i.e. $\mathrm{I}(0) / \mathrm{I}(1)$.

\footnotetext{
${ }^{15}$ See Shahbaz et al. (2017) for further details.

${ }^{16}$ The empirical results at first difference are available upon request from the authors.
} 
Table-3: Bootstrap ARDL Cointegration Analysis (1955-2016)

\begin{tabular}{|c|c|c|c|c|c|c|c|c|c|}
\hline \multicolumn{6}{|c|}{ Bounds Testing Approach to Cointegration } & \multicolumn{4}{|c|}{ Diagnostic tests } \\
\hline Estimated Models & Lag Length & Break Year & $\mathrm{F}_{\mathrm{PSS}}$ & $\mathrm{T}_{\mathrm{DV}}$ & $\mathrm{T}_{\mathrm{IV}}$ & $\bar{R}^{2}$ & $Q-s t a t$ & $L M(2)$ & $J B$ \\
\hline$C_{t}=f\left(I_{t}, Y_{t}, E_{t}, F_{t}, R_{t}\right)$ & $2,2,1,2,1,2$ & $1979^{17}$ & $25.362 *$ & $-11.579 * *$ & $6.893 *$ & 0.8493 & 9.983 & .9184 & 0.2446 \\
\hline$I_{t}=f\left(C_{t}, Y_{t}, E_{t}, F_{t}, R_{t}\right)$ & $2,2,1,1,2,2$ & 1986 & $10.956^{*}$ & $-3.801 * *$ & $-3.108 *$ & 0.7604 & 7.2482 & 1.8650 & 0.3744 \\
\hline$Y_{t}=f\left(C_{t}, I_{t}, E_{t}, F_{t}, R_{t}\right)$ & $2,2,2,2,2,1$ & 1968 & $90.838 *$ & $-4.845^{*}$ & $-2.896 * *$ & 0.6672 & 9.9590 & 2.7132 & 1.2642 \\
\hline$E_{t}=f\left(C_{t}, I_{t}, Y_{t}, F_{t}, R_{t}\right)$ & $2,2,2,1,1,2$ & 2008 & $27.081 * *$ & $-2.714 * *$ & $-2.599 * *$ & 0.7332 & 13.1002 & 1.9394 & 0.2343 \\
\hline$F_{t}=f\left(C_{t}, I_{t}, Y_{t}, E_{t}, R_{t}\right)$ & $2,1,2,1,2,2$ & 1979 & 1.208 & -1.610 & -0.669 & 0.4883 & 8.1031 & 4.2670 & 0.7327 \\
\hline$R_{t}=f\left(C_{t}, I_{t}, Y_{t}, E_{t}, F_{t}\right)$ & $2,1,1,2,2,1$ & 2014 & $27.637 *$ & $-6.415 *$ & $-7.045^{*}$ & 0.8655 & 7.8160 & 4.5977 & 2.0705 \\
\hline$C_{t}=f\left(I_{t}, I_{t}^{2}, Y_{t}, Y_{t}^{2}, E_{t}, F_{t}, F_{t}^{2}, R_{t}\right)$ & $2,2,2,1,1,2,2,2,2$ & 1979 & $24.032 *$ & $-10.170 * * *$ & 6.903* & 0.8390 & 9.9032 & 0.9080 & 0.2006 \\
\hline$I_{t}=f\left(C_{t}, I_{t}^{2}, Y_{t}, Y_{t}^{2}, E_{t}, F_{t}, F_{t}^{2}, R_{t}\right)$ & $2,2,2,1,1,2,2,2,1$ & 1986 & $9.916^{*}$ & $-3.008 * *$ & $-3.112 *$ & 0.7004 & 6.2181 & 1.8053 & 0.3042 \\
\hline$I_{t}^{2}=f\left(C_{t}, I_{t}, Y_{t}, Y_{t}^{2}, E_{t}, F_{t}, F_{t}^{2}, R_{t}\right)$ & $2,2,2,1,1,2,2,2,1$ & 1986 & $10.050 *$ & $-3.611 * *$ & $-3.220^{*}$ & 0.7042 & 7.2103 & 1.8502 & 0.3140 \\
\hline$Y_{t}=f\left(C_{t}, I_{t}, I_{t}^{2}, Y_{t}^{2}, E_{t}, F_{t}, F_{t}^{2}, R_{t}\right)$ & $2,1,2,2,2,1,2,2,1$ & 1968 & $80.810 *$ & $-4.805^{*}$ & $-2.846 * *$ & 0.6470 & 10.9191 & 2.8034 & 1.2892 \\
\hline$Y_{t}^{2}=f\left(C_{t}, I_{t}, I_{t}^{2}, Y_{t}, E_{t}, F_{t}, F_{t}^{2}, R_{t}\right)$ & $2,1,2,2,2,1,2,2,1$ & 1968 & $78.010^{*}$ & $-4.830^{*}$ & $-2.850 * *$ & 0.6469 & 11.0092 & 2.8452 & 1.2908 \\
\hline$E_{t}=f\left(C_{t}, I_{t}, I_{t}^{2}, Y_{t}, Y_{t}^{2}, F_{t}, F_{t}^{2}, R_{t}\right)$ & $2,2,2,1,1,2,2,1,2$ & 2008 & $26.101 * *$ & $-2.724 * *$ & $-2.560 * *$ & 0.7400 & 12.9989 & 1.9090 & 0.2433 \\
\hline$F_{t}=f\left(C_{t}, I_{t}, I_{t}^{2}, Y_{t}, Y_{t}^{2}, E_{t}, F_{t}^{2}, R_{t}\right)$ & $2,1,2,2,2,2,1,2,2$ & 1979 & 2.101 & -1.544 & -0.604 & 0.5001 & 8.0094 & 3.7982 & 0.7020 \\
\hline$F_{t}^{2}=f\left(C_{t}, I_{t}, I_{t}^{2}, Y_{t}, Y_{t}^{2}, E_{t}, F_{t}, R_{t}\right)$ & $2,1,2,2,2,2,1,2,2$ & 1979 & 2.231 & -1.404 & -0.598 & 0.5032 & 7.9082 & 4.0010 & 0.6987 \\
\hline$R_{t}=f\left(C_{t}, I_{t}, I_{t}^{2}, Y_{t}, Y_{t}^{2}, E_{t}, F_{t}, F_{t}^{2}\right)$ & $2,1,1,1,2,2,2,1,1$ & 2014 & $25.440^{*}$ & $-6.405^{*}$ & $-6.985^{*}$ & 0.8057 & 8.0018 & 4.6006 & 1.9876 \\
\hline
\end{tabular}

\footnotetext{
${ }^{17}$ The critical values of $\mathrm{F}_{\mathrm{PSS}}, \mathrm{T}_{\mathrm{DV}}$ and $\mathrm{T}_{\mathrm{IV}}$ for the remaining empirical bootstrapping ARDL models are available upon request from authors.
} 
In order to examine the cointegration between the variables, after noting that they have a mixed order of integration, we have applied the bootstrapping ARDL bounds testing approach in order to test whether cointegration is present. The bootstrapping ARDL bounds testing approach performs better than the traditional ARDL. This approach considers the joint F-test on all lagged level variables, the T-test on the lagged level of the dependent variable and the T-test (new test) on the lagged level of the regressors in order to make a decision regarding cointegration between the variables. Due to these tests, the bootstrapping ARDL test is superior to the simple ARDL bounds testing approach for cointegration.

In bootstrapping ARDL cointegration framework, the T-value and F-value have bootstrapped for examining cointegration between the variables. We report the results of the bootstrapping ARDL bounds testing approach in Table-3. It is noted that the bootstrapping the F-test and T-test on the lagged level of dependent variable reject the null hypothesis that assigned carbon emissions, FDI, economic growth, energy consumption, and public budget in energy research and development expenditures as explanatory variables. Moreover, the T-test on the lagged independent variables also accepts the alternate hypothesis. It implies that the joint F-test, the T-test on the lagged dependent and the T-test on the lagged independent variables validate the existence of cointegration at the $1 \%$ and $5 \%$ levels, respectively. The empirical results are similar as we used FDI, economic growth, energy consumption, and public budget in energy research and development expenditures as dependent variables simultaneously. We failed to attain significant results for the joint F-test, the T-test on lagged dependent and the T-test on the lagged independent variables once we treated carbon emissions, FDI, economic growth, energy consumption, and public budget in energy research and development expenditures as independent variables in the finance demand function. This leads to the acceptance of the null hypothesis and reveals no cointegration. Overall, the empirical results validate the presence of five cointegrating vectors between carbon emissions and its determinants. This confirms the presence of a long-run relationship between FDI, economic growth, energy consumption, financial development, public budget in energy research and development expenditures, and carbon emissions for the French economy over the period 1960-2016.

The diagnostic analysis shows acceptance of the null hypothesis by $Q-$ stat . It opines that the variables have the same population provided by the standard variance analysis, thus confirming the normal distribution of data. ${ }^{18}$ The empirical results indicate that serial

\footnotetext{
${ }^{18}$ See John (2002) for details.
} 
correlation is not present in the empirical models. It means that each variable has an independent observation (Pesaran et al. 2001). The normal distribution of data is also confirmed by the Jarque-Bera test.

Table 4: CO2 Emissions Function Long-Run Analysis (1955-2016)

Dependent Variable: $\ln C_{t}$

\begin{tabular}{|c|c|c|c|c|}
\hline Variable & Coefficient & T-Statistic & Coefficient & T-Statistic \\
\hline Constant & $-53.0743^{*}$ & -2.8749 & $-86.1085^{*}$ & -4.5197 \\
\hline $\ln I_{t}$ & $0.0764 *$ & 3.8639 & $-0.1799 * *$ & -2.4942 \\
\hline $\ln I_{t}^{2}$ & $\ldots$ & $\ldots$ & $0.0130 * *$ & 2.5888 \\
\hline $\ln Y_{t}$ & $9.9745 * *$ & 2.6497 & $16.2905^{*}$ & 4.1804 \\
\hline $\ln Y_{t}^{2}$ & $-0.4743 *$ & -2.7020 & $-0.7531 *$ & -4.1726 \\
\hline $\ln E_{t}$ & $0.6330 *$ & 2.8187 & $0.2833 * *$ & 2.2720 \\
\hline $\ln F_{t}$ & $-0.2503 *$ & -3.2795 & $0.3179 * *$ & 2.5973 \\
\hline $\ln F_{t}^{2}$ & $\ldots$ & $\ldots$ & $-0.0195 * *$ & -2.2276 \\
\hline $\ln R_{t}$ & $-0.0527 * *$ & -2.4447 & $-0.0713^{*}$ & -4.0167 \\
\hline$D_{1979}$ & $-0.1372 *$ & -3.4191 & $-0.0987 * *$ & -2.3456 \\
\hline$R^{2}$ & 0.8930 & 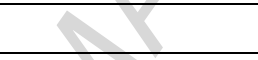 & 0.9211 & \\
\hline $\operatorname{adj}-R^{2}$ & 0.8843 & 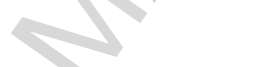 & 0.9067 & \\
\hline F-Statistic & $9.9744 *$ & $\nabla$ & $10.2483 *$ & \\
\hline \multicolumn{5}{|c|}{ Stability Analysis } \\
\hline Test & F-Statistic & P. Value & F-Statistic & P. Value \\
\hline$\chi_{\text {Normal }}^{2}$ & 0.6796 & 0.7118 & 0.4597 & 0.8167 \\
\hline$\chi_{\text {serial }}^{2}$ & 0.7514 & 0.6678 & 0.7754 & 0.6509 \\
\hline$\chi_{A R C H}^{2}$ & 1.7456 & 0.1156 & 1.2450 & 0.2055 \\
\hline$\chi_{\text {Hetero }}^{2}$ & 0.2648 & 0.8765 & 1.2068 & 0.2105 \\
\hline$\chi_{\text {Remsay }}^{2}$ & 1.4725 & 0.1468 & 1.4020 & 0.1908 \\
\hline CUSUM & Stable & & Stable & \\
\hline CUSUMsq & Stable & & Stable & \\
\hline
\end{tabular}

The long-run results are reported in Table-4. We find that the linear and squared terms of real GDP per capita (i.e. the measure of economic growth) have a positive and negative effect on $\mathrm{CO}_{2}$ emissions at the $1 \%$ and $5 \%$ significance levels, respectively. This underscores an inverted U-shape relationship between economic growth and carbon emissions, validating the presence of environmental Kuznets curve (EKC). The theory of EKC indicates that carbon emissions per capita are positively linked with real GDP per capita initially but start to decline after a threshold level of real GDP per capita at later stages of economic development. This empirical finding is consistent with studies, for instance, Esteve and Tamarit (2012) and 
Sephton and Mann (2013) on Spain, Tiwari et al. (2013) on India, Fosten et al. (2015) on UK. In specific to France, Itawa et al. (2010), Shahbaz et al. (2017a), and Can and Gozgor (2017), which validate the presence of the EKC in the French economy. On contrary, studies for instance, Ghosh (2010) on India or more specifically, Mutascu et al. (2016) challenge the validation of the EKC and show that the EKC is not present in the case of France. This can be associated with the novelty of our empirical framework as well as the longer time span of analysis which led to gain a deeper insight into the EKC in France.

The relationship between energy consumption and carbon emissions is positive and significant at the $1 \%$ level. Keeping other things constant, a $1 \%$ increase in energy consumption increases carbon emissions by $0.6330 \%$. This empirical evidence is similar to what Iwata et al. (2010) found for France, Saboori et al. (2012, 2016) for Malaysia, Al-Mulali et al. (2015) for Vietnam, and Shahbaz et al. (2017b) for the US. The relationship between financial development and carbon emissions is negative, and it is statistically significant at the $1 \%$ level. It implies that financial development improves environmental quality by lowering carbon emissions. A $1 \%$ increase in financial development leads to a decline in carbon emissions by $0.2503 \%$ while keeping other things constant. In this regard, the existing evidence on the other countries for instance, Tamazian et al. (2009), Jalil and Feridun (2011), Shahbaz et al. (2013), Nasreen and Anwar (2015,) and Shahbaz et al. (2016) also report that financial development is inversely linked to environmental quality. While on the contrary, Zhang (2011) and Boutabba (2014) show that financial development increases carbon emissions which degrade environmental quality. Whereas, Ozturk and Acaravci (2013) and Dogan and Turkekul (2016) argue that financial development affects carbon emissions insignificantly. The subject study adds to the existing contrasting evidence by providing a very significant evidence on the role of financial development in environmental improvements.

FDI affects carbon emissions positively and significantly. It implies that FDI impedes environmental quality by increasing carbon emissions. If all else is the same, a $1 \%$ increase in FDI leads to an increase in carbon emissions by $0.0764 \%$. This empirical evidence is similar to Shahbaz et al. (2015), who reported that FDI increases $\mathrm{CO}_{2}$ emissions in developed countries like France. On a broader note, this finding is in line with those reported by Ren et al. (2014) on China, Hitam and Borhan (2012) and Lau et al. (2014) on Malaysia, Chandran and Tang (2013) on Asian-5, Sbia et al. (2014) on UAE and Abdouli and Hammami (2017) on MENA countries. While are contrary to those reported by Pao and Tsai's (2011) on BRICS and Zhu et al. (2016) on the ASEAN-5 and/or Paramati et al. (2016) on developing countries. 
However, in specific to the France which is successfully attracting a huge inflow of FDI there are huge ecological implications which must be considered for sustainable economic growth. Public budget in energy research and development expenditures have a negative and statistically significant effect on carbon emissions. We note that a $1 \%$ increase in public budget in energy research and development expenditures reduces $\mathrm{CO}_{2}$ emissions by $0.0527 \%$, keeping other things constant. These empirical findings are consistent with Alvarez-Herranz et al. (2017), while Jordaan et al. (2017) argue that public budget in energy research and development expenditures promotes energy innovations, which reduce energy intensity and lowers carbon emissions. Nonetheless, our findings add to the literature on the nexus between the innovation and technological progress in general and environmental improvement (e.g. Dinda, 2004; Brock and Taylor, 2005, Tang and Tan (2013), Fei et al. (2014) and BalsalobreLorente (2018). Perhaps, in this regard, the subject study specifically focuses on the research and innovation in energy sector which provides us with insight into the direct link between energy research and innovation and environmental improvement.

We have included a squared term of financial development (foreign direct investment) to examine whether the relationship between financial development and carbon emissions (FDI and $\mathrm{CO}_{2}$ emissions) is inverted-U shaped or U-shaped. The results are reported in Table4. We find that linear and squared terms of financial development respectively have a positive and negative effect on carbon emissions. This shows the presence of an inverted-U shaped, thus supporting the environmental Kuznets curve hypothesis between financial development and carbon emissions. It is found that a $1 \%$ increase in financial development increases carbon emissions by $0.3179 \%$, while a negative estimate of the squared term corroborates the delinking of carbon emissions and financial development after a threshold level of domestic credit to the private sector. This empirical evidence is in line with studies of the existing literature such as Tamazain et al. (2009), Shahbaz et al. (2013a), Nasreen and Anwar (2015), and Shahbaz et al. (2016), which also confirm the presence of the EKC hypothesis between financial development and carbon emissions. Contrarily, Shahbaz et al. (2013b) report the absence of the EKC i.e. the U-shaped relationship between financial development and $\mathrm{CO}_{2}$ emissions.

Similarly, the effect of the linear and squared terms of foreign direct investment is negative and positive on carbon emissions, respectively. It shows the presence of a U-shaped relationship between foreign direct investment and $\mathrm{CO}_{2}$ emissions negating the presence of the EKC hypothesis. This shows that foreign direct investment reduces carbon emissions but increases it after a threshold level of foreign direct investment per capita. This empirical 
evidence is contrary to Bao et al. (2008) who find an inverted- $U$ shaped association between FDI investment and carbon emissions. Similarly, Shahbaz et al. (2015) could not prove the presence of an inverted-U relationship between FDI and carbon emissions in developed countries such as France.

In the long span of time, the high value of $\mathrm{R}^{2}$ indicates that carbon emissions are well elucidated by all regressors such as FDI, economic growth, energy consumption, financial development, and public budget in energy research and development expenditures. The longrun models are found significant at the $1 \%$ significance level. The Durbin Watson test statistic shows the absence of autocorrelation, while the normal distribution of the error term is also confirmed. The diagnostic analysis further reveals the absence of serial correlation and autoregressive conditional heteroscedasticity. The presence of white heteroscedasticity is not validated and a well-designed specification of the empirical model is confirmed. The CUSUM and CUSUMsq tests are also applied for examining the reliability of long-run empirical results. Figure-1 and 2 show the results of the CUSUM and CUSUMsq tests. It is noted that the plots of the CUSUM and CUSUMsq are between the critical bounds and they are statistically significant at $5 \%$.

Table 5: $\mathrm{CO}_{2}$ Emissions Function Short-Run Analysis (1955-2016)

\begin{tabular}{|c|c|c|c|c|}
\hline \multicolumn{5}{|c|}{ Dependent Variable: $\Delta \ln C_{t}$} \\
\hline Variable & Coefficient & T-Statistic & Coefficient & T-Statistic \\
\hline Constant & $-0.0194 *$ & -3.0343 & $-0.0229 *$ & -3.3310 \\
\hline$\Delta \ln I_{t}$ & $0.0371 *$ & 3.4084 & -0.0345 & -1.4049 \\
\hline$\Delta \ln I_{t}^{2}$ & & $\ldots$. & 0.0960 & 0.3282 \\
\hline$\Delta \ln Y_{t}$ & $0.2026 * *$ & 2.4895 & $0.1218^{*}$ & 4.0184 \\
\hline$\Delta \ln Y_{t}^{2}$ & -0.0743 & -0.7020 & -0.6501 & -1.1020 \\
\hline$\Delta \ln E_{t}$ & $0.5543 *$ & 4.5231 & $0.4503 * *$ & 2.2020 \\
\hline$\Delta \ln F_{t}$ & 0.0014 & 3.2795 & 0.0017 & 1.5071 \\
\hline$\Delta \ln F_{t}^{2}$ & .... & .... & -0.0143 & -0.3134 \\
\hline$\Delta \ln R_{t}$ & $-0.0133 * *$ & -2.2112 & $-0.0306 * *$ & -2.0067 \\
\hline$D_{1979}$ & -0.0187 & -0.3070 & -0.0230 & -1.1371 \\
\hline$E C M_{t-1}$ & $-0.1352 *$ & -3.1489 & $-0.0816 * *$ & -2.1325 \\
\hline$R^{2}$ & 0.7270 & & 0.7307 & \\
\hline $\operatorname{adj}-R^{2}$ & 0.6902 & & 0.6822 & \\
\hline F-Statistic & $6.1874 *$ & & $9.20403 *$ & \\
\hline \multicolumn{5}{|c|}{ Stability Analysis } \\
\hline Test & F-Statictic & P.Value & F-Statictic & P.Value \\
\hline
\end{tabular}




\begin{tabular}{|c|c|c|c|c|}
\hline$\chi_{\text {Normal }}^{2}$ & 2.2688 & 0.3216 & 2.8990 & 0.2345 \\
\hline$\chi_{\text {serial }}^{2}$ & 2.2272 & 0.1189 & 2.2567 & 0.1203 \\
\hline$\chi_{\text {ARCH }}^{2}$ & 0.0200 & 0.8880 & 0.1066 & 0.7452 \\
\hline$\chi_{\text {Hetero }}^{2}$ & 2.1789 & 0.1093 & 1.4512 & 0.1716 \\
\hline$\chi_{\text {Re } m s a y}^{2}$ & 1.5734 & 0.1567 & 1.4578 & 0.1702 \\
\hline CUSUM & Stable & & Stable & \\
\hline CUSUMsq & Stable & Stable & \\
\hline Note: The asterisks * and ** denote significance at the 1\% and 5\% levels, respectively. \\
\hline
\end{tabular}

The short-run results are reported in Table-5. We find that in short run, FDI is positively and significantly linked with $\mathrm{CO}_{2}$ emissions, which validates the presence of the pollution-haven hypothesis. The relationship between economic growth and carbon emissions is an inverted-U shaped and insignificant. It implies that the presence of the environmental Kuznets curve is insignificantly, but the linear term of economic growth has a positive and significant effect on carbon emissions. Energy consumption impedes environmental quality significantly by increasing carbon emissions. Financial development has a positive and significant impact on carbon emissions. Public budget in energy research and development expenditures reduce carbon emissions significantly. We have also included the squared terms of foreign direct investment and financial development to confirm whether the relationship between foreign direct investment and carbon emissions is inverted-U shaped (similarly between financial development and carbon emissions). The results show that the relationship between foreign direct investment and carbon emissions is U-shaped but insignificant. We also find an insignificant inverted- $U$ shaped association between financial development and $\mathrm{CO}_{2}$ emissions. The $E C M_{t-1}$ estimates have a negative sign and significant at the $1 \%$ and $5 \%$ levels for both models, respectively. The statistical significance of $E C M_{t-1}$ estimates corroborates the established long-run relationship between carbon emissions and its determinants. The significance of $E C M_{t-1}$ estimates also helps in assessing the speed of adjustment. The estimates of $E C M_{t-1}$ are -0.1352 and -0.0816 , respectively. We note that the short run deviations towards long run are corrected by $13.52 \%$ and $8.16 \%$, respectively. It will take 7 years and 9 months (and 12 years and 3 months) for reaching to long-run equilibrium path.

The short run empirical models are significant at the $1 \%$ and $5 \%$ levels. The empirical models are well described by the independent variables i.e. $\mathrm{R}^{2}$ is 0.7270 and 0.7307 . The autocorrelation between carbon emission and the residual term is not validated. The diagnostic analysis shows the normal distribution of error term. The empirical confirmation is 
also valid for the absence of serial correlation. The absence of white heteroscedasticity, as well as auto-conditional heteroscedasticity is also confirmed. The Ramsey reset test confirms the well-specification of the short-run empirical model. The empirical results by the CUSUM and the CUSUMsq tests also validate the reliability of the short-run estimates. ${ }^{19}$

\section{Figure 1: Plot of CUSUM}

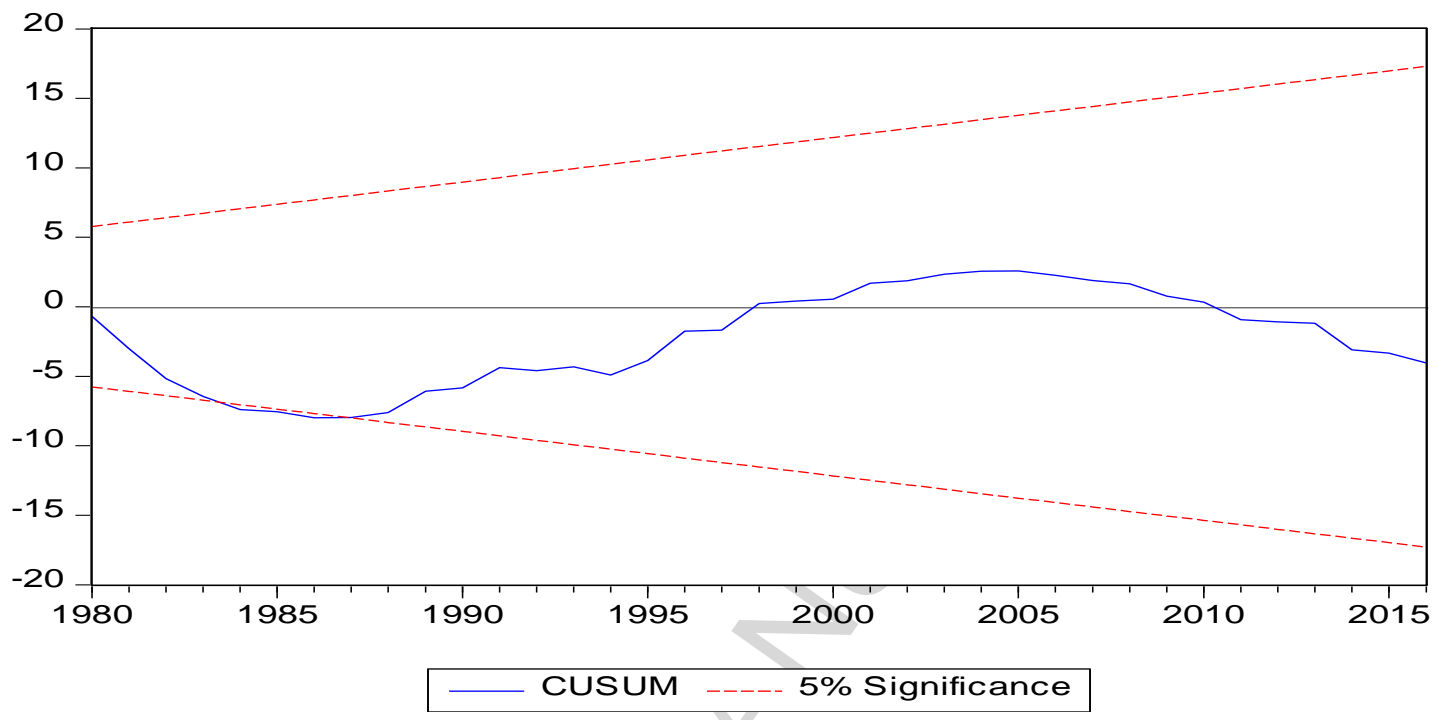

Figure 2: Plot of CUSUMsq

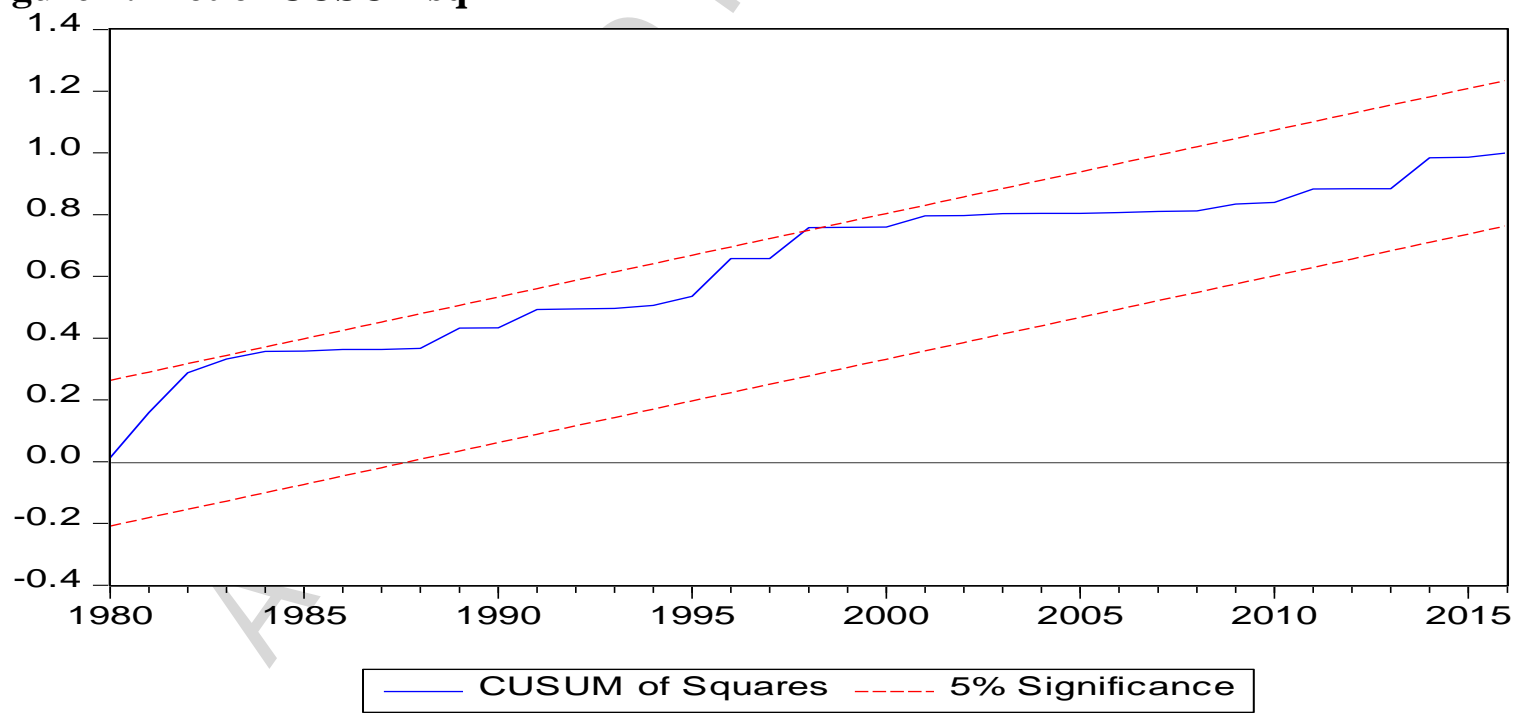

The results of Granger causality based on the bootstrapping ARDL are reported in Table-6 and we bootstrap F-value (with p-value) for Granger causality based on bootstrapping ARDL. Foreign direct investment causes carbon emissions, and in return carbon emissions cause foreign direct investment. The presence of a feedback effect between economic growth

\footnotetext{
${ }^{19}$ We have provided empirical results of CUSUM and CUSUMsq for short run to conserve space but the other results are available upon request from the authors.
} 
and carbon emissions is validated. The relationship between energy consumption and carbon emissions is bidirectional. Public budget in energy research \& development expenditures cause carbon emissions and it is similar from the opposite side. Carbon emissions are the cause of financial development and is also similar from the opposite side i.e. the financeleads-emissions hypothesis. The unidirectional causality is noted for running from financial development to economic growth and energy consumption. Financial development causes public budget in energy research \& development expenditures positively. Foreign direct investment is the negative cause of financial development. The feedback effect exists between energy consumption and economic growth.

Table-6: Granger Causality based on Bootstrapping ARDL (1955-2016)

\begin{tabular}{|c|c|c|c|c|c|c|c|}
\hline \multirow[t]{2}{*}{ Variables } & \multicolumn{7}{|c|}{ Short Run Causality } \\
\hline & $\Delta \ln C_{t}$ & $\Delta \ln I_{t}$ & $\Delta \ln Y_{t}, \Delta \ln Y_{t}^{2}$ & $\Delta \ln E_{t}$ & $\Delta \ln F_{t}$ & $\Delta \ln R_{t}$ & $\begin{array}{c}\text { Break } \\
\text { Year }\end{array}$ \\
\hline$\Delta \ln C_{t}$ & $\cdots$ & $\begin{array}{c}1.4265(-) \\
{[0.2518]}\end{array}$ & $\begin{array}{c}1.1668(+) \\
{[0.2024]} \\
\end{array}$ & \begin{tabular}{|c|}
$33.5205(+)$ \\
{$[0.0000]^{*}$} \\
\end{tabular} & $\begin{array}{l}4.3908(+) \\
{[0.0187]^{* *}}\end{array}$ & $\begin{array}{c}0.4872(-) \\
{[0.6179]}\end{array}$ & 1979 \\
\hline$\Delta \ln I_{t}$ & $\begin{array}{c}0.9003(-) \\
{[0.4141]}\end{array}$ & $\cdots$ & $\begin{array}{c}0.4353(+) \\
{[0.6499]}\end{array}$ & $\begin{array}{c}0.0178(+) \\
{[0.9823]}\end{array}$ & $\begin{array}{c}0.1035(-) \\
{[0.9018]}\end{array}$ & $\begin{array}{c}2.4155(-) \\
{[0.1016]}\end{array}$ & 1986 \\
\hline$\Delta \ln Y_{t}, \Delta \ln Y_{t}^{2}$ & $\begin{array}{c}3.3789(-) \\
{[0.0436]^{* *}}\end{array}$ & $\begin{array}{c}0.5993(+) \\
{[0.5549]}\end{array}$ & & $\begin{array}{c}0.1038(-) \\
{[0.8975]}\end{array}$ & $\begin{array}{c}0.3991(+) \\
{[0.6787]}\end{array}$ & $\begin{array}{c}0.2209(-) \\
{[0.8027]}\end{array}$ & 2008 \\
\hline$\Delta \ln E_{t}$ & $\begin{array}{c}25.4040(+) \\
{[0.0000]^{*}}\end{array}$ & $\begin{array}{c}0.0206(-) \\
{[0.9796]}\end{array}$ & $\begin{array}{c}0.1680(+) \\
{[0.8459]}\end{array}$ & $\ldots$ & $\begin{array}{c}1.5513(+) \\
{[0.2239]}\end{array}$ & $\begin{array}{c}0.0246(+) \\
{[0.9756]}\end{array}$ & 1968 \\
\hline$\Delta \ln F_{t}$ & $\begin{array}{c}2.0245(-) \\
{[0.1395]}\end{array}$ & $\begin{array}{c}0.2658(-) \\
{[0.7677]}\end{array}$ & $\begin{array}{c}0.3789(+) \\
{[0.6866]}\end{array}$ & $\begin{array}{c}0.4382(+) \\
{[0.6478]}\end{array}$ & $\ldots$ & $\begin{array}{c}1.0666(-) \\
{[0.3555]}\end{array}$ & 1979 \\
\hline \multirow[t]{2}{*}{$\Delta \ln R_{t}$} & $\begin{array}{c}0.0195(-) \\
{[0.9807]}\end{array}$ & $\begin{array}{l}1.1342(-) \\
{[0.3316]} \\
\end{array}$ & $\begin{array}{c}1.8317(+) \\
{[0.1730]} \\
\end{array}$ & $\begin{array}{c}0.6909(-) \\
{[0.5608]}\end{array}$ & $\begin{array}{c}0.0658(-) \\
{[0.9363]} \\
\end{array}$ & $\cdots$ & 2014 \\
\hline & \multicolumn{7}{|c|}{ Long Run Causality } \\
\hline$\Delta \ln C_{t}$ & $\cdots$ & $\begin{array}{c}11.3050(+) \\
{[0.0000]^{*}}\end{array}$ & $\begin{array}{c}16.3866(+) \\
{[0.0000]^{*}}\end{array}$ & \begin{tabular}{|c|}
$15.3060(+)$ \\
{$[0.0000]^{*}$}
\end{tabular} & $\begin{array}{c}12.3456(-) \\
{[0.0000]^{*}}\end{array}$ & $\begin{array}{l}2.4509(-) \\
{[0.0186]^{*}}\end{array}$ & 1979 \\
\hline$\Delta \ln I_{t}$ & $\begin{array}{l}5.0584(+) \\
{[0.0345]^{* *}}\end{array}$ & $\ldots$ & $\begin{array}{c}5.1431(-) \\
{[0.0301]^{* *}}\end{array}$ & $\begin{array}{l}8.5712(-) \\
{[0.0003]^{*}}\end{array}$ & $\begin{array}{c}5.1528(-) \\
{[0.0299]^{* *}}\end{array}$ & $\begin{array}{l}5.1037(+) \\
{[0.0301]^{* *}}\end{array}$ & 1986 \\
\hline$\Delta \ln Y_{t}, \Delta \ln Y_{t}^{2}$ & $\begin{array}{c}9.09891(-) \\
{[0.0000]^{*}}\end{array}$ & $\begin{array}{c}5.3145(-) \\
{[0.0262]^{* *}}\end{array}$ & $\ldots$ & $\begin{array}{l}8.8769(+) \\
{[0.0005]^{* *}}\end{array}$ & $\begin{array}{l}9.4109(+) \\
{[0.0000]^{*}}\end{array}$ & $\begin{array}{l}5.1621(-) \\
{[0.0295]^{* *}}\end{array}$ & 2008 \\
\hline$\Delta \ln E_{t}$ & $\begin{array}{c}5.7393(-) \\
{[0.0195]^{* *}} \\
\end{array}$ & $\begin{array}{l}4.7154(-) \\
{[0.0356]^{* *}}\end{array}$ & $\begin{array}{c}4.2817(-) \\
{[0.0485]^{* *}}\end{array}$ & $\ldots$ & $\begin{array}{c}6.1771(-) \\
{[0.0187]^{* *}} \\
\end{array}$ & $\begin{array}{c}6.0034(-) \\
{[0.0150]^{* *}}\end{array}$ & 1968 \\
\hline$\Delta \ln F_{t}$ & .... & .... & .... & .... & $\ldots$ & .... & 1979 \\
\hline$\Delta \ln R_{t}$ & $\begin{array}{c}5.1127(+)^{* *} \\
{[0.0298]}\end{array}$ & $\begin{array}{c}9.0353(+)^{*} \\
{[0.0056]}\end{array}$ & $\begin{array}{c}16.0485(+)^{*} \\
{[0.0000]}\end{array}$ & $\begin{array}{c}9.8956(-)^{*} \\
{[0.0031]}\end{array}$ & $\begin{array}{c}5.0213(+)^{* * *} \\
{[0.0265]}\end{array}$ & $\cdots$ & 2014 \\
\hline
\end{tabular}

The signs of the coefficient for independent variables are also shown in small brackets. Based on those signs of coefficients, we conclude that foreign direct investment and carbon 
emissions lead each other positively. Economic growth adds to carbon emissions which in return reduces economic growth. Energy consumption increases $\mathrm{CO}_{2}$ emissions, but in response $\mathrm{CO}_{2}$ emissions reduce energy consumption. Foreign direct investment negatively causes energy consumption and it is similar from the opposite side. The positive feedback effect between energy consumption and economic growth shows the importance of the consistent supply of energy and exploring new of energy for long-run economic growth. Public budget in energy research \& development expenditures lead to decline in carbon emissions, and in return a decline in $\mathrm{CO}_{2}$ emissions encourages the government to increase public budget in energy research \& development expenditures for further environmental quality improvements to attain long-run economic growth. A bidirectional but negative causality is found between energy consumption and public budget in energy research \& development expenditures. Financial development reduces energy consumption which in resulting, reduces carbon emissions but economic growth is positively caused by financial development.

The results imply that economic growth increases carbon emissions and carbon emissions reduce economic growth. This shows that a decline in economic growth lowers energy consumption, which subsequently lowers economic growth as a feedback effect between exists between economic growth and energy consumption. It implies that in order to control for environmental degradation and improving economic growth, the government should pay more attention to exploring new renewable energy sources to add them to the energy-mix. In doing so, financial sector may be used as an economic tool in order to direct the financial resources towards more research \& development activity in the energy sector as financial development and public budget in energy research \& development expenditures have negative causal effect on carbon emissions. Financial development causes energy consumption and economic growth negatively and positively respectively. It implies that the financial sector allocates financial resources to productive investment ventures that implement modern and energy efficient technologies for production. This will not only enhance domestic production but also improves environmental quality by lowering energy intensity. The use of modern and energy efficient technology helps in avoiding the wastage of energy that can be saved for future generations.

In the short run, we note the presence of energy-led-emissions as energy consumption positively causes carbon emissions. Financial development has a positive and unidirectional causal effect on $\mathrm{CO}_{2}$ emissions. The neutral effect exists between foreign direct investment and carbon emissions. Carbon emissions cause economic growth and energy consumption 
negatively and positively respectively. Neither economic growth causes foreign direct investment nor foreign direct investment causes economic growth. Public budget in energy research \& development expenditures has a negative but insignificant effect on carbon emissions and it is true from the opposite side.

\section{Conclusion and Policy Implications}

In the context of the French efforts and commitment to deal with environmental and ecological issues as well the intention to restructure its economy, this study investigates the effects of relevant contributory economic factors on the environmental degradation. In so doing, we focus on the impact of foreign direct investment on $\mathrm{CO}_{2}$ emissions and also incorporate financial development and public expenditure on energy sector research \& development in the carbon emissions function for the French economy for the period 19552016.

For the empirical purpose, our intention was to apply the most recent and novel set of techniques with a number of benefits which we discussed at length in the methodology section of this treatise. Specifically, we have applied the ADF and SOR structural break unit root tests in order to examine the order of integration of the underlying data series. Furthermore, we analyzed and tested for the presence of cointegration between carbon emissions and their determinants by employing the bootstrapping ARDL cointegration approach. In the final part of the analysis and in order to examine the causal relationship among the underlying variables of interest, we applied the bootstrapping ARDL-based Granger causality.

In the light of our empirical results, we can hereby conclude the existence of cointegration between carbon emissions and their underlying determinants. More specifically, we conclude that in France, an increase in foreign direct investment worsens the environmental quality by increasing carbon emissions. This is a prima facie manifestation of the Pollution-Heaven Hypothesis. The results also lead us to conclude that the relationship between economic growth and carbon emissions has an inverted-U shaped, which supports the EKC hypothesis. Energy consumption was also found to be an important factor in boosting carbon emissions. On the positive side, the financial development leads to a decline in carbon emissions. The relationship between public expenditure on energy research \& development and carbon emissions was also found to be negative, implying that research \& development expenditures on energy innovations is useful in improving environmental quality by lowering carbon emissions.

The bootstrapping ARDL Granger causality analysis reveals the presence of a 
feedback effect between foreign direct investment and carbon emissions. The causal relationship between economic growth and carbon emissions was found to be bidirectional. It showed that the energy consumption causes carbon emissions, and subsequently carbon emissions cause energy consumption. The bidirectional causality also exists between public budget in energy research \& development expenditures and carbon emissions. Financial development causes foreign direct investment, economic growth, energy consumption, and public expenditure on energy research \& development and carbon emissions.

In term of economic and ecological policy formulation, our findings have profound implications for an economy intended to balance between economic development and environmental sustainability in general and for France in particular. Considering the French economic outlook, which is on one hand starving for capital investment (specifically FDI) and on the other hand a French global leadership and commitment to deal with the climate challenges which requires to be an example for others, it appears that there is a crucial tradeoff the French policymakers may face. In the light of analysis and findings of this study for which we drew on more than half a century data of the French economy, it is evident that FDI has been a contributory factor in increasing environmental degradation. Hence, on one hand, FDI is required to boost economic growth and tackle with domestic socio-economic challenges, and on the other hand, in the light of historical results, FDI can impede environmental quality and efforts to deal with the climate issues. Concomitantly, this would imply that in future policy formulation and while encouraging FDI, France should consider the environmental aspect of it and urge investments in the environmentally more sustainable sectors.

The relationship between the economic growth and environmental degradation was inverted-U shaped, which supports the EKC hypothesis. In terms of policy implication, it may suggest that the successful efforts to increase growth may result in an increase in environmental degradation only in the short-term. Hence, one may argue that for the sake of long-term economic interest, these effects might be condoned in the policy formulation. However, when compared with the ecological realities and commitments (including the Paris Agreement), this line of reasoning is fundamentally flawed. Specifically, as the commitments have been made to decrease carbon emissions in the form of Nationally Determined Contributions (NDCs), including the EU and its member states has expressed a "binding target of an at least $40 \%$ domestic reduction in greenhouse gas emissions by 2030 compared to 1990". Concomitantly, any negative gesture or ecologically unsustainable policy stance, particularly by a country like France, will have detrimental effects on the global efforts to deal 
with environmental challenges. Hence, it is vital that even the short-term negative impacts of growth on environmental degradation must be taken into account and economic and environmental policy formulation.

The importance of the financial sector and financial stability for real economy is paramount and a widely-discussed and debated subject in economics. However, our results suggest that there is also an important dimension of financial and ecological stability for the environment. Our results suggest that financial development leads to a decline in carbon emissions and environmental degradation. Hence, we conclude that the "financial stability and environmental sustainability are two sides of a coin". This has an important financial policy implication as the French financial sector can play a vital role in tackling environmental challenges. Particularly, if we put this together with the earlier discussed implication of FDI. A sustainable financial intermediation can play an important part dealing with the environmental degradation. Nonetheless, the energy innovation can also complement the financial sector positive role and endeavour to improve environmental quality.

In the light of our results, it is evident that there is a strong negative relationship between research and development expenditures in energy innovation and carbon emissions in France. This implies that research and development expenditures in energy innovation is a crucial factor to consider in policy formulation, as it significantly improves environmental quality by lowering carbon emissions. Concurrently, it is intuitive to suggest that in the future the policy formulation role of financial development and research and development in the energy innovation should be categorically considered. This will help France address the environmental challenges and honour its commitments. Indeed on the French part, it would be leading from the front and by example!

\section{References}

Abbasi, F. Riaz, K. 2016. $\mathrm{CO}_{2}$ emissions and financial development in an emerging economy: An augmented VAR approach. Energy Policy. 90, 102-114.

Abdouli, M. Hammami, S. 2017. Investigating the causality links between environmental quality, foreign direct investment and economic growth in MENA countries. International Business Review. 26, 264-278.

Akbostancı, E., Türüt-Aşık, S. Tunç, G. İ. 2009. The relationship between income and environment in Turkey: Is there an environmental Kuznets curve? Energy Policy. 37, 861867.

Alvarez-Herranz, A., Balsalobre-Lorente, D., Shahbaz, M. Cantos, J. M.2017. Energy innovation and renewable energy consumption in the correction of air pollution levels. Energy Policy. 105, 386-397.

Al-Mulali, U. Saboori, B. Ozturk, I. 2015. Investigating the environmental Kuznets curve hypothesis in Vietnam. Energy Policy. 76, 123-131.

Al-Mulali, U. Ozturk, I. 2016. The investigation of environmental Kuznets curve hypothesis 
in the advanced economies: The role of energy prices. Renewable and Sustainable Energy Reviews. 54, 1622-1631.

Al-mulali, U. Tang, C. F. 2013. Investigating the validity of pollution haven hypothesis in the gulf cooperation council (GCC) countries. Energy Policy, 60, 813-819.

Andreoni, J. Levinson, A. 2001. The simple analytics of the environmental Kuznets curve. Journal of Public Economics. 80, 269-286.

Andersson, M. Braunerhjelm, P. Thulin, P.2011. Creative Destruction and Productivity Entrepreneurship by type, sector and sequence, Swedish Entrepreneurship Forum, Woking Paper No. 2011:08.

Ang, J. B. 2007. $\mathrm{CO}_{2}$ emissions, energy consumption, and output in France. Energy Policy. $35,10,4772-4778$.

Apergis, N. 2016. Environmental Kuznets curves: New evidence on both panel and countrylevel CO2 emissions. Energy Economics, 54, 263-271.

Apergis, N., Christou, C. Gupta, R. 2017. Are there Environmental Kuznets Curves for US state-level CO2 emissions? Renewable and Sustainable Energy Reviews, 69, 551-558.

Arrow, K., Bolin, B. Costanza, R. Folke, C. Holling, C.S. Janson, B.-O., Levin, S., Maler, K.G., Perrings, C., Pimental, D.1996. Economic growth, carrying capacity, and the environment. Ecological Economics. 6, 13-15.

Atasoy, B. S. 2017. Testing the environmental Kuznets curve hypothesis across the U.S.: Evidence from panel mean group estimators. Renewable and Sustainable Energy Reviews. 77, 731-747.

Baek, J. 2016. A new look at the FDI-income-energy-environment nexus: Dynamic panel data analysis of ASEAN. Energy Policy. 91, 22-27.

Baek, J. and Kim, H. S. 2013. Is economic growth good or bad for the environment? Empirical evidence from Korea. Energy Economics. 36, 744-749.

Balsalobre-Lorentea, D., Shahbaz, M., Roubaud, D. Farhani, S. 2018. How economic growth, renewable electricity and natural resources contribute to $\mathrm{CO} 2$ emissions? Energy Policy. 113, 356-367.

Batten, J. A. Kinateder, H. Szilagyi, P.G. Wagner, N.F. 2018. Addressing COP21 using a stock and oil market integration index, Energy Policy, 116, 127-136,

Bao, Q., Chen, Y. Song, L.2008. The environmental consequences of foreign direct investment in China. Environment and Development Economics. 16, 71-92.

Becker, R., Enders, W. and Lee, J. (2006). A stationarity test in the presence of unknown number of smooth breaks. Journal of Time Series Analysis, 27(3), 381-409.

Bekhet, H. A. Matar, A. Yasmin, T.2017. $\mathrm{CO}_{2}$ emissions, energy consumption, economic growth, and financial development in GCC countries: Dynamic simultaneous equation models. Renewable and Sustainable Energy Reviews. 70, 117-132.

Bierens, H. J. (1997), Nonparametric Cointegration Analysis, Journal of Econometrics. 77, 379-404.

Borio, C. 2011. Rediscovering the macroeconomic roots of financial stability policy: journey, challenges and a way forward. Working Paper No. 354, BIS.

Bölük, G. Mert, M.2015. The renewable energy, growth and environmental Kuznets curve in Turkey: An ARDL approach. Renewable and Sustainable Energy Reviews, 52, 587-595.

Boutabba, M. A. 2014. The impact of financial development, income, energy and trade on carbon emissions: Evidence from the Indian economy. Economic Modelling, 40, 33-41.

Brock, W.A. Taylor, M. S. 2005. Economic growth and the environment: a review of theory and empirics. In: Aghion, P., Durlauf, S.N. (Eds.), Handbook of Economic Growth 1. Elsevier B.V, Amsterdam, Netherland, 1749-1819. 
Bruvoll, A., Fæhn, T. Strøm, B. 2003. Quantifying central hypotheses on environmental Kuznets curves for a rich economy: a computable general equilibrium study. Scottish Journal of Political Economy. 50, 149-173.

Business France, 2017. The International Development of The French Economy, 2016 Annual Report: Foreign investment in France, available at [http://en.businessfrance.fr/Media/Default/Bilan\%202016\%20version\%20finale/2017_RA_B F_UK_Global.pdf] accessed at $21^{\text {st }}$ December 2017.

Çalışkan, H. K.2015. Technological Change and Economic Growth. Procedia - Social and Behavioral Sciences. 195, 649-654.

Can, M. and Gozgor, G. 2017. The impact of economic complexity on carbon emissions: evidence from France. Environmental Science and Pollution Research. 24, 16364-16370.

Chandran, V. G. R. Tang, C. F. 2013. The impacts of transport energy consumption, foreign direct investment and income on $\mathrm{CO} 2$ emissions in ASEAN-5 economies. Renewable and Sustainable Energy Reviews, 24, 445-453.

Chang, S. C. 2015. Effects of financial developments and income on energy consumption. International Review of Economics \& Finance. 35, 28-44.

Charfeddine, L. Khediri, K. B. 2016. Financial development and environmental quality in UAE: Cointegration with structural breaks. Renewable and Sustainable Energy Reviews. 55, 1322-1335.

Çoban, S. Topcu, M.2013. The nexus between financial development and energy consumption in the EU: A dynamic panel data analysis. Energy Economics, 39, 81-88.

Davies, R. B. (1977). Hypothesis testing when a nuisance parameter is present only under the alternative. Biometrika, 64, 247-5 4.Dinda, S. 2004. Environmental Kuznets Curve Hypothesis: A Survey. Ecological Economics. 49, 431-455.

Dogan, E. Seker, F. 2016. The influence of real output, renewable and non-renewable energy, trade and financial development on carbon emissions in the top renewable energy countries. Renewable and Sustainable Energy Reviews. 60, 1074-1085.

Dogan, E. Turkekul, B. 2016. $\mathrm{CO}_{2}$ emissions, real output, energy consumption, trade, urbanization and financial development: testing the EKC hypothesis for the USA. Environmental Science and Pollution Research. 23, 1203-1213.

Easley, J. 2017. Trump cements 'America First' doctrine with Paris withdrawal. The Hill, available at [http://thehill.com/homenews/administration/336014-trump-cements-americafirst-doctrine-with-paris-withdrawal] accessed on 30th July 2017.

Esteve, V. Tamarit, C. 2012. Is there an environmental Kuznets curve for Spain? Fresh evidence from old data. Economic Modelling. 29, 2696-2703.

Fei, Q., Rasiah, R. Shen, L. J. 2014. The clean energy-growth nexus with CO2 emissions and technological innovation in Norway and New Zealand. Energy and Environment. 25, 13231344.

Financial Times.2017.China and EU offer sharp contrast with US on climate change, Available at [https://www.ft.com/content/06ccfc32-45d4-11e7-8519-9f94ee97d996] accessed on $21^{\text {st }}$ December 2017.

Fodha, M. Zaghdoud, O. 2010. Economic growth and pollutant emissions in Tunisia: An empirical analysis of the environmental Kuznets curve. Energy Policy. 38, 1150-1156.

Fosten, J. Morley, B. Taylor, T. 2012. Dynamic misspecification in the environmental Kuznets curve: Evidence from $\mathrm{CO} 2$ and $\mathrm{SO} 2$ emissions in the United Kingdom. Ecological Economics. 76, 25-33.

Gallant, A. (1981). On the bias in flexible functional forms and an essentially unbiased form: The fourier flexible form, Journal of Econometrics, 15. 211-245.

Gallant, A. Souza, G. (1991). On the asymptotic normality of Fourier flexible form estimates, Journal of Econometrics, 50, 329-353. 
GFCI.2017.The Global Financial Centres Index 22 available at [http://www.luxembourgforfinance.com/sites/luxembourgforfinance/files/files/GFCI22_Repo rt.pdf] accessed $28^{\text {th }}$ December 2017.

Ghosh, S. 2010. Examining carbon emissions economic growth nexus for India: A multivariate cointegration approach. Energy Policy. 38, 3008-3014.

Goh, S.K. Yong, J. Y. Lau, C. C. Tang, T. C. (2017). Bootstrap ARDL on energy-growth relationship for 22 OECD countries, Applied Economics Letters, 24, 1464-1467.

Grossman, G. M. Krueger, A. B. 1991.Environmental Impacts of the North American Free Trade Agreement. NBER Working Paper 3914.

Hitam, M. B. Borhan, H. B.2012. FDI, Growth and the Environment: Impact on Quality of Life in Malaysia. Procedia - Social and Behavioral Sciences. 50, 333-342.

Hultman, N. 2017. The galvanized world response to Trump's Paris Agreement decision, available at [https://www.brookings.edu/blog/planetpolicy/2017/06/07/the-galvanized-worldresponse-to-trumps-paris-agreement-decision/] accessed on 12th August 2017.

Islam, F., Shahbaz, M., Ahmed, A. U. Alam, M. M. 2013. Financial development and energy consumption nexus in Malaysia: A multivariate time series analysis. Economic Modelling. 30, 435-441.

Jalil, A. Feridun, M. 2011. The impact of growth, energy and financial development on the environment in China: A cointegration analysis. Energy Economics. 33, 284-291.

Javid, M. Sharif, F.2016. Environmental Kuznets curve and financial development in Pakistan. Renewable and Sustainable Energy Reviews. 54, 406-414.

Jiang, L., Zhou, H-F., Bai, L. Zhou, P.2017. Does foreign direct investment drive environmental degradation in China? An empirical study based on air quality index from a spatial perspective. Journal of Cleaner Production, 1-9.

Jordaan, S. M., ElizabethRomo-Rabago, E., McLeary, R., Reidy, L., Nazari, J. Herremans, I. M.2017. The role of energy technology innovation in reducing greenhouse gas emissions: A case study of Canada. Renewable and Sustainable Energy Reviews. 78, 1397-1409.

Kim, D. Perron. P. (2009). Unit root tests allowing for a break in the trend function at an unknown time under both the null and alternative hypotheses, Journal of Econometrics. 148, $1-13$.

Kivyiro, P. and Arminen, H.2014. Carbon dioxide emissions, energy consumption, economic growth, and foreign direct investment: Causality analysis for Sub-Saharan Africa. Energy. 74, 595-606.

Kottasová, I.2017.France is the weakest of Europe's big 3 economies, available at [http://money.cnn.com/2017/04/19/news/economy/france-electioneconomy/index.html?iid=EL $\}$ accessed on $21^{\text {st }}$ December 2017.

Komen, R., Gerking, S. Folmer, H. 1997. Income and environmental protection: empirical evidence from OECD countries. Environmental and Development Economics. 2, 505-515.

Lau, L. S., Choong, C. K. Eng, Y. K.2014. Investigation of the environmental Kuznets curve for carbon emissions in Malaysia: Do foreign direct investment and trade matter? Energy Policy. 68, 490-497.

Lee, J. W. 2013. The contribution of foreign direct investment to clean energy use, carbon emissions and economic growth. Energy Policy. 55, 483-489.

Leiserowitz, A., Maibach, E., Roser-Renouf, C., Rosenthal, S. Cutler, M. 2016. Politics \& Global Warming, November 2016. Yale University and George Mason University. New Haven, CT: Yale Program on Climate Change Communication.

Liu, Y., Hao, Y. Gao, Y. 2017. The environmental consequences of domestic and foreign investment: Evidence from China. Energy Policy. 108, 271-280.

Lorente, D. B. Álvarez-Herránz, A. 2016. Economic growth and energy regulation in the environmental Kuznets curve. Environmental Science and Pollution Research. 23, 16478- 
16494.

Mahalik, M. K., Babu, S., Loganthan, N. Shahbaz, M (2016), Does financial development intensify energy consumption in Saudi Arabia? Renewable and Sustainable Energy Reviews, 75, 1022-1034.

McNown, R. Sam, C. Y. Goh, S. K. (2018). Bootstrapping the autoregressive distributed lag test for cointegration, Applied Economics, 50, 1509-1521.

Mielnik, O. Goldemberg, J. 2002. Foreign direct investment and decoupling between energy and gross domestic product in developing countries. Energy Policy, 30, 87-89.

Morgan, J. 2016. Paris COP 21: Power that Speaks the Truth? Globalization. 13, 943-951.

Mutascu, M., Pereau, J-C. Ursu, E.2016. A wavelet analysis of the environmental Kuznets curve in France. Cahiers du GREThA, working paper n²016-10.

Narayan, P. K. Narayan, S.2010. Carbon dioxide emissions and economic growth: Panel data evidence from developing countries. Energy Policy. 38, 661-666.

Nasir, M. A, Ahmed, F., Ahmed, M. Wu, J.2015. Financial and economic stability as 'two sides of a coin': Non-crisis regime evidence from the UK based on VECM. Journal of Financial Economic Policy. 7, 327-353.

Nasir, M. A., Rizvi, S. A. Rossi, M. 2017, A Treatise on Oil Price Shocks and their Implications for the UK Financial Sector: Analysis Based on Time-Varying Structural VAR Model. The Manchester School. . doi:10.1111/manc.12206

Nasir, M. Rehman, F. U.2011. Environmental Kuznets Curve for carbon emissions in Pakistan: An empirical investigation. Energy Policy. 39, 1857-1864.

Nasreen, S. Anwar, S. 2015. The impact of economic and financial development on environmental degradation: An empirical assessment of EKC hypothesis. Studies in Economics and Finance. 32, 485-502.

OECD.2002. Foreign Direct Investment for Development, MAXIMISING BENEFITS, MINIMISING COSTS, available

[https://www.oecd.org/investment/investmentfordevelopment/1959815.pdf] accessed at $19^{\text {th }}$ December 2017.

OECD.2014. FRANCE Structural reforms: impact on growth and options for the future, available at [https://www.oecd.org/economy/France_StructuralReforms.pdf] accessed at $21^{\text {st }}$ December 2017.

Onafowora, O. A. Owoye, O.2014. Bounds testing approach to analysis of the environment Kuznets curve hypothesis. Energy Economics. 44, 47-62.

Omay, T. Emirmahmutoğlu, F. (2017). The comparison of power and optimization algorithms on unit root testing with smooth transition. Computational Economics, 49, 623651.

Omri, A., Nguyen, D. K. Rault, C. 2014. Causal interactions between CO2 emissions, FDI, and economic growth: Evidence from dynamic simultaneous-equation models. Economic Modelling. 42, 382-389.

Omri, A., Daly, S., Rault, C. Chaibi, A. 2015. Financial development, environmental quality, trade and economic growth: What causes what in MENA countries. Energy Economics. 48, 242-252.

Özokcu, S. Özdemir, Ö.2017. Economic growth, energy, and environmental Kuznets curve. Renewable and Sustainable Energy Reviews. 72, 639-647.

Ozturk, I. Acaravci, A. 2013. The long-run and causal analysis of energy, growth, openness and financial development on carbon emissions in Turkey. Energy Economics. 36, 262-267.

Pal, D. and Mitra, S. K. 2017. The environmental Kuznets curve for carbon dioxide in India and China: Growth and pollution at crossroad. Journal of Policy Modelling. 39, 371-385.

Pao, H. -T. and Tsai, C. -M. 2011. Multivariate Granger causality between CO2 emissions, energy consumption, FDI (foreign direct investment) and GDP (gross domestic product): 
Evidence from a panel of BRIC (Brazil, Russian Federation, India, and China) countries. Energy. 36, 685-693.

Paramati, S. R., Ummalla, M. Apergis, N. 2016. The effect of foreign direct investment and stock market growth on clean energy use across a panel of emerging market economies. Energy Economics. 56, 29-41.

Pazienza, P.2015. The relationship between CO2 and Foreign Direct Investment in the agriculture and fishing sector of OECD countries: Evidence and policy considerations. Intellectual Economics. 9, 55-66.

Pazienza, P. 2015b. The environmental impact of the FDI inflow in the transport sector of OECD countries and policy implications. International Advances in Economic Research, 21, 105-116.

Pesaran, M.H. and Shin, Y. (1999). “An Autoregressive Distributed Lag Modelling Approach to Cointegration Analysis." Econometrics and Economic Theory in the 20th Century: The Ragnar Frisch Centennial Symposium, Strom, S. (ed.) Cambridge University Press.

Pesaran, M. H., Shin, Y. Smith, R. J. (2001). Bounds testing approaches to the analysis of level relationships. Journal of Applied Econometrics, 16, 289-326.

Raworth, K.2017. Doughnut Economics: Seven Ways to Think Like a 21st-Century Economist, Random House Business, ISBN-13: 978-1847941374

Ren, S., Yuan, B., Ma, X. Chen, X.2014. International trade, FDI (foreign direct investment) and embodied $\mathrm{CO} 2$ emissions: A case study of Chinas industrial sectors. China Economic Review. 28, 123-134.

Reuters.2017. France's Macron says will continue to press Trump on climate agreement, available at [https://www.reuters.com/article/us-g20-germany-climatechange-macron/francesmacron-says-will-continue-to-press-trump-on-climate-agreement-idUSKBN19T0RP] accessed on $21^{\text {st }}$ December 2017.

Robalino-López, A., Mena-Nieto, A., García-Ramos, J. E. Golpe, A. A.2015. Studying the relationship between economic growth, $\mathrm{CO} 2$ emissions, and the environmental Kuznets curve in Venezuela (1980-2025). Renewable and Sustainable Energy Reviews, 41, 602-614.

Saboori, B., Sulaiman, J. Mohd, S. 2012. Economic growth and CO2 emissions in Malaysia: A cointegration analysis of the Environmental Kuznets Curve. Energy Policy. 51, 184-191.

Saboori, M., Sulaiman, J. Saidatulakmal, M. 2016. Environmental Kuznets curve and energy consumption in Malaysia: A cointegration approach. Energy Sources, Part B: Economics, Planning and Policy. 11, 861-867.

Saha, D.Muro, M.2017. Clean energy's shifting reality: Venture capital recedes, but what's next? Available at [https://www.brookings.edu/blog/the-avenue/2017/05/30/clean-energyventure-capital/] accssed on 12th August 2017.

Sadorsky, P. 2010. The impact of financial development on energy consumption in emerging economies. Energy Policy. 38, 2528-2535.

Sadorsky, P. 2011. Financial development and energy consumption in Central and Eastern European frontier economies. Energy Policy. 39, 999-1006.

Salahuddin, M., Alam, K., Ozturk, I. Sohag, K. 2018. The effects of electricity consumption, economic growth, financial development and foreign direct investment on $\mathrm{CO} 2$ emissions in Kuwait. Renewable and Sustainable Energy Reviews. 81, 2002-2010.

Sbia, R., Shahbaz, M. Hamdi, H. 2014. A contribution of foreign direct investment, clean energy, trade openness, carbon emissions and economic growth to energy demand in UAE. Economic Modelling. 36, 191-197.

Schumpeter, J. A. 1942. Capitalism, Socialism and Democracy. London: Routledge. 82-83.

Sephton, P. Mann, J. 2013. Further evidence of an Environmental Kuznets Curve in Spain. Energy Economics. 36, 177-181.

Shahbaz, M., Tiwari, A. K. Nasir, M. 2013. The effectsof financial development, economic 
growth, coal consumption and trade openness on $\mathrm{CO} 2$ emissions in South Africa. Energy Policy. 61, 1452-1459.

Shahbaz, M., Nasreen, S., Abbas, F. Anis, O.2015. Does foreign direct investment impede environmental quality in high-, middle-, and low-income countries? Energy Economics. 51, 275-287.

Shahbaz, M., Mutascu, M. Azim, P. 2013a. Environmental Kuznets curve in Romania and the role of energy consumption. Renewable and Sustainable Energy Reviews, 18, 165-173.

Shahbaz, M., Solarin, S. A., Mahmood, H. Arouri, M. 2013b. Does financial development reduce $\mathrm{CO} 2$ emissions in Malaysian economy? A time series analysis. Economic Modelling. $35,145-152$.

Shahbaz, M., Lean, H. H. Shabbir, M. S.2012. Environmental Kuznets Curve hypothesis in Pakistan: Cointegration and Granger causality. Renewable and Sustainable Energy Reviews. 16, 2947-2953.

Shahbaz, M., Shahzad, S. J. H., Ahmad, N. Alam, S.2016. Financial development and environmental quality: The way forward. Energy Policy, 98, 353-364.

Shahbaz, M., Jam, F. A., Bibi, S. Loganathan, N.2016. Multivariate granger causality between $\mathrm{CO} 2$ emissions, energy intensity and economic growth in Portugal: evidence from cointegration and causality analysis. Technological and Economic Development of Economy. 22, 47-74.

Shahbaz, M., Zeshan, M. and Afza, T. (2012). Is energy consumption effective to spur economic growth in Pakistan? New evidence from bounds test to level relationships and Granger causality tests. Economic Modelling, 29, 2310-2319.

Shahbaz, M., Shafiullah, M., Papavassiliou, V. G. Hommoudeh, S.2017a. The $\mathrm{CO}_{2}$-growth nexus revisited: A nonparametric analysis for the G7 economies over nearly two centuries. Energy Economics. 65, 183-193.

Shahbaz, M., Omay, T. and Roubaud, D. (2017). The Sharp and Smooth Breaks Unit Root Testing of Renewable Energy Consumption: The Way Forward. Paper presented in $1^{\text {st }}$ International Conference on Energy, Finance and the Macroeconomy, 22-24 November, 2017, Montpellier Business School, Montpellier, France.

Shahbaz, M., Solarin, S. A., Hammoudeh, S. Shahzad, S. J. H. 2017b. Bounds testing approach to analyzing the environment Kuznets curve hypothesis with structural beaks: The role of biomass energy consumption in the United States. Energy Economics. 68, 548-565.

Solarin, S. A., Al-Mulali, U., Musah, U. Ozturk, I. 2017. Investigating the pollution haven hypothesis in Ghana: An empirical investigation. Energy. 124, 706-719.

Song, M-L., Zhang, W. Wang, S. H. 2013. Inflection point of environmental Kuznets curve in Mainland China. Energy Policy. 57, 14-20.

Stern D. I. (2004). The rise and fall of the environmental Kuznets curve. World Development, 32, 1419-1439.

Tamazian, A. Rao, B. B. 2010. Do economic, financial and institutional developments matter for environmental degradation? Evidence from transitional economies. Energy Economics. $32,137-145$.

Tamazian, A., Chousa, J. P. Vadlamannati, K. C. 2009. Does higher economic and financial development lead to environmental degradation: Evidence from BRIC countries. Energy Policy. 37, 246-253.

Tang, C. T. Tan, E. C.2013. Exploring the nexus of electricity consumption, economic growth, energy prices and technology innovation in Malaysia. Applied Energy. 104, 297-305. Tang, C. F. Tan, B. W. 2015. The impact of energy consumption, income and foreign direct investment on carbon dioxide emissions in Vietnam. Energy. 79, 447-454.

Tiwari, A. K., Shahbaz, M. Hye, Q. M. A. 2013. The environmental Kuznets curve and the role of coal consumption in India: Cointegration and causality analysis in an open economy. 
Renewable and Sustainable Energy Reviews. 18, 519-527.

Torras, M. and Boyce, J.1998. Income, inequality, and pollution: a reassessment of the Environmental Kuznets Curve. Ecological Economics. 25, 147-160.

Turner, K. and Hanley, N. 2011. Energy efficiency, rebounds and the environmental Kuznets curve. Energy Economics. 33, 709-720.

UNCTD, (2018), World Investment Report 2018, United Nations Conference on Trade and Development, Geneva, Switzerland.

United Nations Framework Convention on Climate Change.2018. Intended Nationally Determined Contributions (INDCs), available

at http://www4.unfccc.int/submissions/indc/Submission\%20Pages/submissions.aspx

Zhang, Y. J. 2011. The impact of financial development on carbon emissions: An empirical analysis in China. Energy Policy. 39, 2197-2203.

Zhang, C. and Zhou, X. 2016. Does foreign direct investment lead to lower CO2 emissions? Evidence from a regional analysis in China. Renewable and Sustainable Energy Reviews. 58, 943-951.

Zhu, H., Duan, L., Guo, Y. Yub, K. 2016. The effects of FDI, economic growth and energy consumption on carbon emissions in ASEAN-5: Evidence from panel quantile regression, Economic Modelling. 58, 237-248. 


\section{Highlights}

- Role of FDI, Financial Development, and Energy Innovations in environmental degradation in France.

- France attracting high inflow of FDI in recent years.

- FDI degrades the environment and thus supports the pollution-haven hypothesis in France.

- Financial development and energy research innovations lower carbon emissions and improve the French environmental quality.

- Financial development and energy research innovation are required to play an important role in improving environmental quality in France. 